$$
\begin{gathered}
\text { 한의학적 치로로 호전된 안면비대칭 } 5 \text { 계 } \\
\text { 신정민 }{ }^{1,2 *}, \text { 안진향 }^{1}, \text { 이진혁 }^{1} \\
\text { 1참진한의원, }{ }^{2} \text { 차의과대학교대학원 통합의학과 }
\end{gathered}
$$

\title{
The Effect of Korean Medical Treatments for Facial asymmetry Patients : Five Cases Report
}

\author{
Jeongmin Shin ${ }^{1,2^{*}}$, Jin-hyang Ahn ${ }^{1}$, Jin-hyuk Lee ${ }^{1}$ \\ ${ }^{1}$ Charmjin Korean Medicine Clinic \\ ${ }^{2}$ Department of Integrative medicine, Graduate school, CHA Medicine University
}

Objectives: The purpose of this study was to investigate the effect of Korean medicine treatment on facial asymmetric treatment in 5 cases of facial asymmetry correction by non - surgical treatment such as acupucture, chuna treatment , FCST (Functional cerebrospinal technique) and cranial osteopathy.

Methods: We analyzed the initial charts of 5 patients who had undergone facial asymmetry in a Korean medicine clinic and measured the position and distance using the photograph, lateral cephalograms, and whole body radiograms. The results were as follows.

Results: To quantify both soft and hard tissues to confirm the results of Korean medicine treatment of facial asymmetry, soft tissues quantitatively measure the displacement of the face, the slope of the left and right eyes, and the slope of the lip in order to grasp the positional displacement of the mandible. As a result, on the average, the correction effect as measured by the angle difference between $\mathrm{A}$ and $\mathrm{C}$ is $1.8 \pm 0.57$, the correction effect as measured by the angle difference between $\mathrm{B}$ and $\mathrm{C}$ is $1.4 \pm 0.89$, and the angle difference between $\mathrm{D}$ and the horizontal plane is $1.9 \pm 0.89$, and the angle difference between $\mathrm{E}$ and the horizontal plane is $1.9 \pm 0.89$. The result of reduced angle difference between $\mathrm{A}$ and $\mathrm{C}$ means that the head position shifted from the center of the body to the unilateral side was shifted to the center. The decrease in the angle difference between $\mathrm{B}$ and $\mathrm{C}$ means the restoration of the maxillary distortion relative to the mandible. In hard tissues, numerical values were measured based on the skull standard. The average distortion of the skull was $1.9 \pm 0.67$, and the distortion of the lower eye was $1.4 \pm 0.41$.

Conclusion: General studies on facial asymmetric treatment are limited to treatments such as surgery and orthodontics. However, this study confirmed the possibility that facial asymmetry could be corrected by Korean medical treatment consisting of reversible non-surgical treatment rather than irreversible treatment such as surgery or orthodontic treatment. In particular, Korean medicine treatment is effective for muscular asymmetry, soft asymmetry, functional asymmetry, etc. The facial asymmetric treatment of Korean medicine is not limited to the face-centered correction, but the asymmetry of the whole body may be corrected as well.

\section{Key Words : Facial asymmetry, Non-surgical facial correction, Korean medicine treatment of facial asymmetry, Facial acupuncture, cranial osteopathy, FCST}

\footnotetext{
- Received : 31 July 2019

- Revised : 26 August 2019

- Accepted : 27 August 2019

- Correspondence to : Jeongmin Shin

Charmjin building, Nonhyeon-ro 85. Road43, Gangnam-gu, Seoul, Republic of korea

Tel : +82-2-538-7712, Fax : +82-2-538-4478, E-mail : hiranya5382@gmail.com
} 


\section{서 론}

일반적으로 척추동물은 정중선을 기준으로 각각의 구조물이 거울의 이미지처럼 대칭적인 구조를 형성 하는 경향성이 있다 ${ }^{1)}$. 안면비대칭은 미간 중심부에 서 턱 끝 중심선까지 얼굴의 중심선을 그었을 때 상 악 또는 하악의 중심이 좌측이나 우측으로 편위되었 거나 안면고경이나 폭경의 차이가 있는 경우를 의미 한다. 임상에서 안모검사시 대칭적인 정상인도 방사 선 사진을 촬영해 경조직을 평가해보면 정도의 경중 은 있지만 일정 정도의 비대칭은 있는 것으로 알려 져 있다2). 실제 발생 과정에 발생할 수 있는 생물학 적인 요소나 환경적인 원인 때문에 인간은 완벽하게 좌우대칭으로 성장하기는 힘들달. 그래서 과거에는 경미한 안면비대칭은 인간의 신체적인 특징에 의해 필연적으로 발생하는 증상의 하나로 인식되어서 치 료의 대상이 아니었다. 그러나 최근에는 셀프 카메라 로 자신의 얼굴을 많이 찍게 되고 동영상을 통해 본 인의 얼굴 비대칭을 인식하기 쉬운 다양한 사회환경 적인 요인에 의해 경미한 안면비대칭을 치료의 대상 으로 받아들이는 사람들이 늘었다.

안면비대칭에 대한 기존의 연구는 수술을 필요로 하는 악안면 기형이나 하악과두의 과도한 성장으로 인한 안면비대칭에만 국한되어 있다 ${ }^{4,5)}$. 또한 턱관절 과의 연관성을 고찰한 연구나 치아교정 치료로 안면 비대칭, 특히 턱 비대칭을 개선했다는 치과학적인 연 구는 많이 진행되어왔다 ${ }^{1,6,7,15,19)}$. 그러나 안면비대칭 이 전신적인 문제와 동반되어 발생한다는 연구7), 치 아 교정없는 치료나 비수술적인 치료로 안면비대칭 을 개선했다는 연구는 부족한 실정이다. 이에 연구진 은 본 증례를 통해 침술이나 수기 요법과 같은 비수 술적 요법으로 안면비대칭을 교정 가능성을 파악해 보고자 하였다.

\section{연구방법}

1. 연구 대상

본 연구는 증례 연구로, 안면비대칭을 주소로 내원 하여 다른 병원에서의 치료를 동시에 병행하지 않고 본원에서 한방치료만을 받은 환자 5 례의 의무 기록 과 안면 사진 및 서울 소재의 영상의학과에 의뢰하 여 촬영한 엑스레이 영상을 이용하여 연구를 진행하 였다.

\section{2. 연구 윤리}

본 연구는 보건복지부 지정 공용 기관 생명윤리 위원회(IRB)의 정규 심의를 받은 후에 시행되었다. (승인번호: P01-201908-21-006) 본 연구는 미성년자 를 포함하지 않은 증례보고 연구로 별도의 서면 동 의 과정은 생략되었으며 연구 대상자의 사진은 특정 개인을 알아볼 수 없는 형태로 가공하여 사용하였다.

\section{3. 치료방법}

매 내원 시 4개의 혈자리 (태양, 하관, 예풍, 협거) 를 취혈해 침 치료를 진행하였다. 그리고 인체 자세 의 음양 불균형과 턱관절의 불균형을 평가해 구강내 장치를 착용하여 턱관절과 하악과두의 상대적인 위 치를 조절하는 생리적 자극 요법인 기능적 뇌척주요 법인 FCST (functional cerebrospinal technique) ${ }^{8,9)}$ 에서 활용하는 인상제를 이용한 맞춤형 교정기인 음 양 균형 장치와 표준형 균형 장치를 착용하는 치료 를 진행하였다. 이와 병행해 의사의 손을 이용한 단 순 추나 치료를 통해 근막의 이완을 유도한 다음 고 속진폭기법의 경추 교정을 진행했다. 환자의 상태에 따라 CST(cranial sacral therapy) pillow를 후두부에 5 분정도 둔 뒤에 골반교정기인PBT(pelvic balance tool)와 정골수기요법은 내원 시 환자 상태에 따라 조합해서 진행하였다. 5 명의 환자는 위에서 언급된 종류의 치료를 매회 다른 조합으로 총 10 14회 진행 하였다. 
1) 교정기

(1) 맞춤형 교정 장치 (Yinyang Balance

\section{Appliance)}

맞춤형 교정장치 제작에는 부가 중합형 폴리비닐 실리콘 인상제(GC Dental products cor., 일본)와 측 정바, 측정 페이퍼(진바이오텍, 대한민국)를 사용하 였다. 양쪽 근육의 긴장도, 측경부 회전 검사를 진행 해 좌우 긴장도가 같아지는 높이를 찾아 양쪽 어금 니로 물게 한 다음 두가지 인상제를 섞어서 굳기 전 에 치아 모양을 본떠서 굳힌 다음 10 분 착용하였다 ${ }^{10)}$ (Fig. 1).

(2) 표준형 교정 장치 IBA (Intraoral balancing appliance)

표준형 교정 장치 IBA (진바이오텍, 대한민국)인 $\mathrm{A} 4$ 나 $\mathrm{A} 5$ (이하 $\mathrm{ABA} 4, \mathrm{ABA} 5$ )를 하루 8시간을 평 균적으로 착용하였다. $\mathrm{ABA}$ 는 치열과 구강의 악궁 사이즈에 따라 1 호에서 10 호까지 다양화되어 제작된 장치로 구강 구조에 따라 최적의 상태로 착용할 수 있도록 통계 처리하여 정확성을 기울인 구강장치이 다 ${ }^{11)}$ (Fig. 2).

2) 경추 교정: 근막 이완 추나 치료를 진행해 손에 서 느껴지는 근막의 이완 반응을 확인한 다음 의사

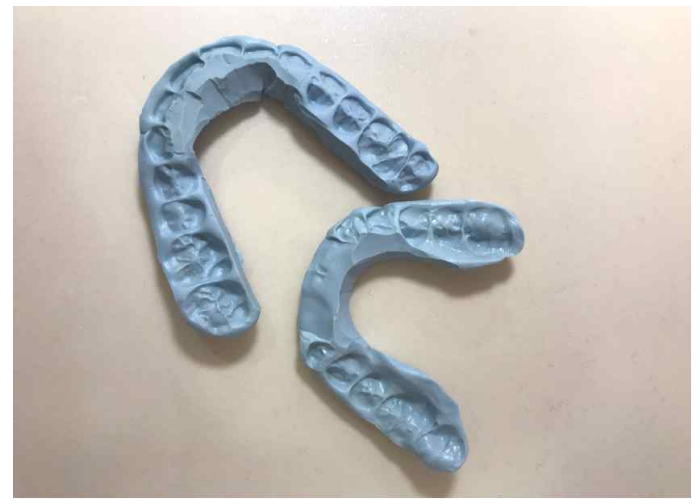

Fig. 1. Yinyang Balance Appliance
의 양손을 좌우 측두부와 턱까지 잡고 머리를 측굴 한 뒤 30 도 가량 후굴을 동시에 진행하여 젖힌 뒤 고속 저진폭 기법(순간교정기법)을 좌우측 모두 진행 해서 손으로 경추부(1번 7번까지)를 만졌을 때 한쪽 으로 돌출되어 있는 부분이 없는 상태로 교정해 주 었다.

3) FCST 교정 도구를 이용한 치료: CST pillow (진바이오텍, 대한민국)을 후두부로 5 분간 베도록 하 거나 골반 교정 도구인 $\mathrm{PBT}$ (진바이오텍, 대한민국) 를 이마, 가슴, 골반의 전상장골극 (ASIS: Anterior Superior Iliac Spine)에 올려 놓고 7분 정도 방치하 였다. 환자 상태에 따라 총 9회 11회 진행하였다.

4) 교정침: 태양(EX-HN5), 하관(ST7), 협거(ST6), 예풍(TH17) (제조사: 동방침 $0.2 \times 0.3$. 대한민국)을 자침 후 15 분 유침하였다 ${ }^{10)}$.

\section{5) 정골 수기요법}

정골의학에서 진행하는 교근 수기요법, 측두근 수 기요법, 익상근 수기요법을 진행하였다. 교근 수기요 법은 교근의 근육의 결을 따라 의사의 손의 어제부 와 검지 약지까지 감싸듯이 접촉해 경결점을 문질 러 부드럽게 밀어준 다음 더 이상 밀리지 않는다고

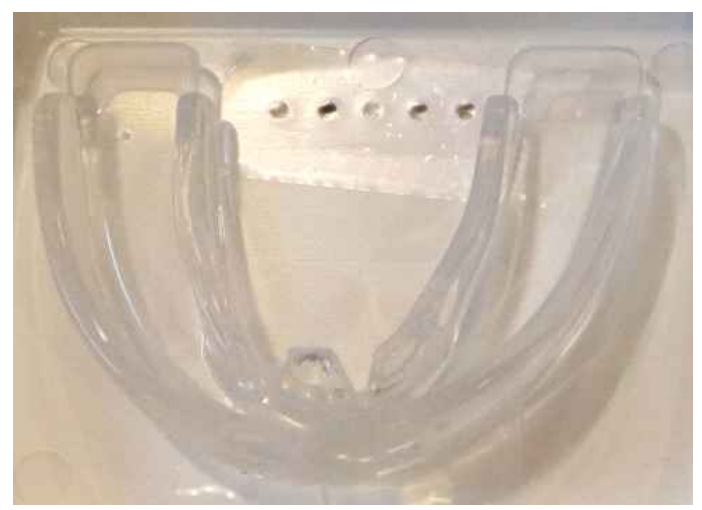

Fig. 2. Standard Balance Appliance: IBA 


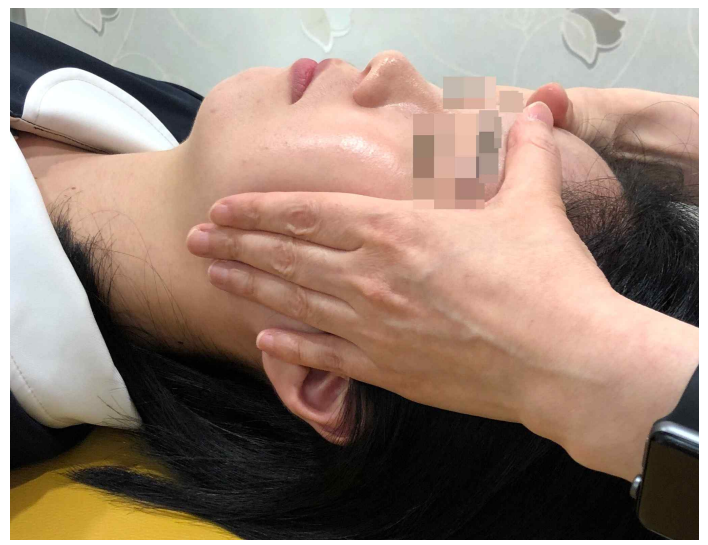

Fig. 3. Massester technique

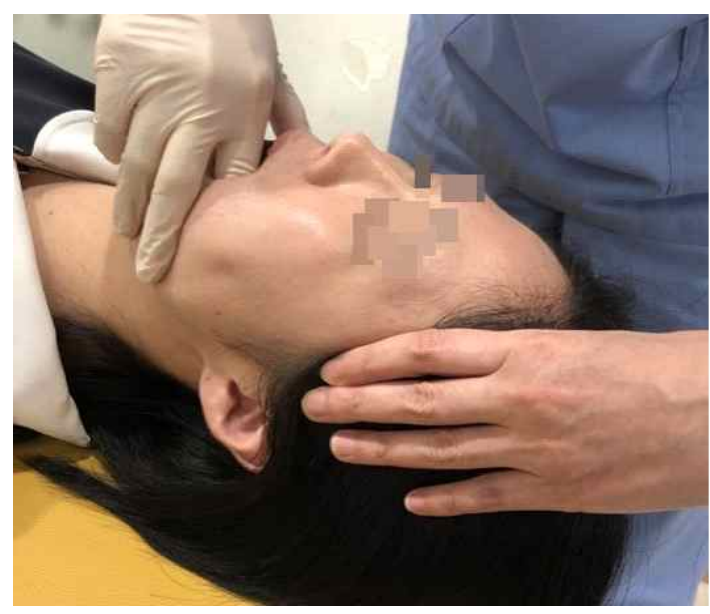

Fig. 5. Pterygoid techniques

느껴지면 손의 힘을 풀어주었다(Fig. 3). 측두근 수기 요법은 양쪽 측두근을 검지 약지 4 개의 손가락으로 측두부를 감싸고 엄지손가락은 백회부에 지지한 다 음 측두근을 넓게 감싸진 네 손가락에 느껴지는 경 결점을 문질러서 풀어주었다(Fig. 4). 익상근 수기요 법은 일회용 장갑을 낀 상태로 검지를 이용해 입 안 쪽에 상하악이 만나는 굴곡점의 경결 부위를 밀어주 듯이 풀어주었다 ${ }^{12)}($ Fig. 5).

6) 운동법

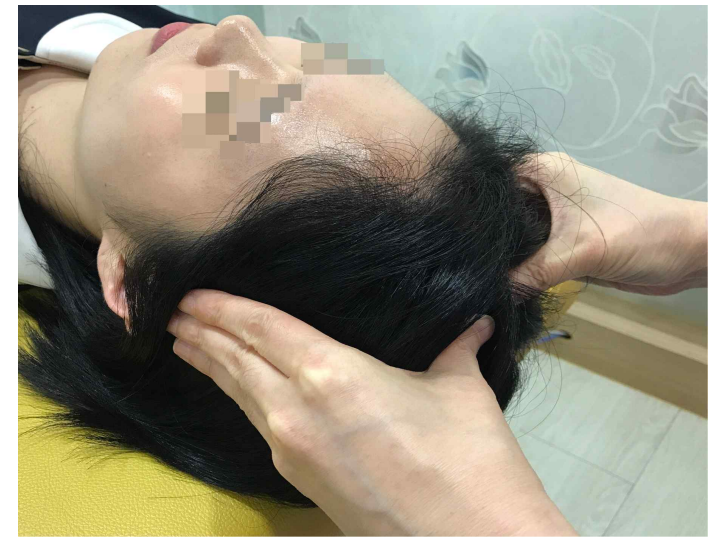

Fig. 4. Temporalis technique

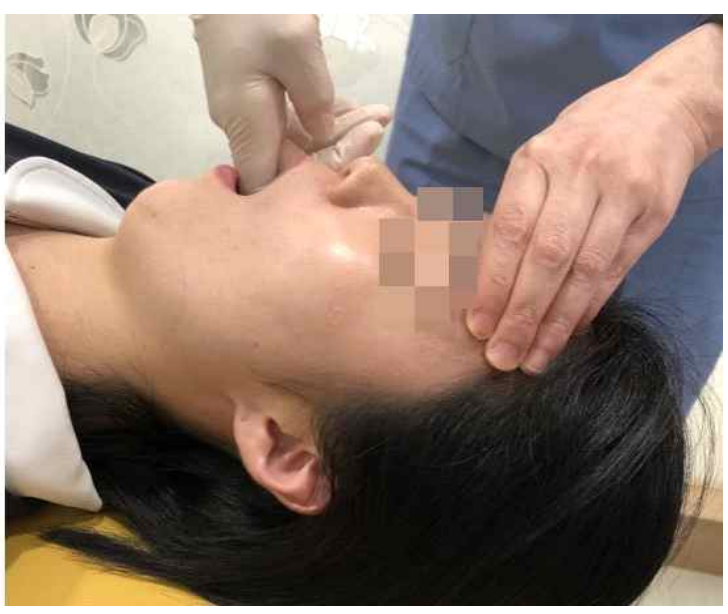

턱관절과 주변 근육이 이완되도록 아래턱을 벌렸 다 닫았다 하는 턱관절 이완 운동을 매 치료 과정에 100 회 병행하여 진행하였다.

\section{5. 평가방법}

1) 일반 사진 평가

캐논 dslr EOS 450D, 렌즈EFS 18 55mm로 $2 \mathrm{~m}$ 떨어진 거리에서 촬영한 뒤 사진 편집 프로그램인 포토 스케이프를 이용해 아래와 같이 기준점을 정해 서 선을 그어준 뒤 새한의료기에서 제작한 360 도 


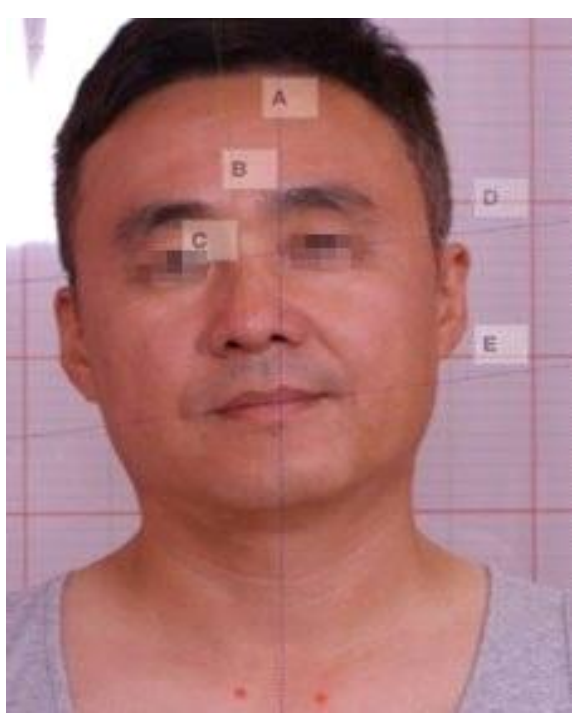

Fig. 6. Photography analysis

The line drawn vertically at the midpoint of both clavicles (A)

The line from the end of the chin to center point of both medial eyebrows (B)

The line from the middle point of both clavicles to the center point of both medial eyebrows (C)

The line drawn horizontally between the lowest point of the left and right black eyes (D)

The line drawn horizontally between the ends of left lateral mouth and right one (E)

$17 \mathrm{~cm}$ 고니어미터를 이용해 각각의 기준점 사이의 각도를 측정하였다. 길이는 아이폰 앱의 유틸리티 중 눈금자를 이용해 소수점 단위까지 거리를 측정하였다.

본 연구에서는 연조직의 비대칭의 완화 정도를 정 량적으로 평가하기 위해 $\mathrm{A}$ 과 $\mathrm{C}$ 가 이루는 각도, $\mathrm{B}$ 과 $\mathrm{C}$ 가 이루는 각도와 $\mathrm{D}$ 와 $\mathrm{E}$ 가 각각 수평면과 이루는 각도를 측정하였다 ${ }^{13)} . \mathrm{A}$ 와 $\mathrm{C}$ 가 이루는 각도는 몸통 의 중심인 쇄골을 기준으로 머리가 기울어진 정도를 파악하는 지표이며 $\mathrm{B}$ 와 $\mathrm{C}$ 는 두개골의 중심인 미간 의 중심점에서 턱 끝이 기울어진 정도를 파악하기 위한 지표로 활용하였다. 또한 $\mathrm{D}$ 와 수평면이 이루는 각도는 양쪽 눈의 기울어짐을 파악하기 위해 $\mathrm{E}$ 와 수 평면이 이루는 각도는 양쪽 입술 끝이 기울어진 정 도를 파악하기 위한 지표로 사용하기 위해 측정하였 다(Fig. 6).

2) 방사선 영상 평가

본 연구에서는 두부 방사선 사진을 이용해 기준점

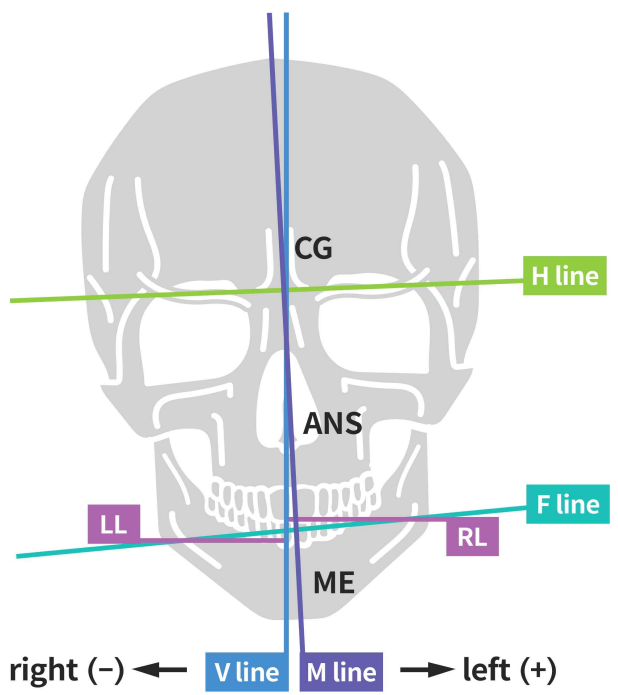

Fig. 7. chephalography analysis

\section{Horizontal baseline connecting both Latero-orbitale points $(\mathrm{H})$}

The line drawn horizontally Both antegonial notch (F)

The line drawn from GristaGalli to ANS (V)

The line from the point where $\mathrm{H}$ line meet with $\mathrm{V}$ line to menton where radioactivity increases on the radiograph (M)

을 설정해 거리와 각도를 계측한 수치의 좌우 비교 를 통해 치료 전후의 경조직 변화를 정량적으로 평 가하였다. V라인과 M라인 두 선이 이루는 각도와 $\mathrm{H}$ 라인과 $\mathrm{V}$ 라인과 이루는 각도, $\mathrm{F}$ 라인과 $\mathrm{V}$ 라인이 이 루는 각도의 차이를 측정하여서 상악과 하악의 기울 어진 정도를 측정하였다. $\mathrm{V}$ 선에서 하악골의 antegonial notch의 양쪽을 직각으로 이은 두 선의 길이 $(\mathrm{LL}$ 과 $\mathrm{RL})$ 를 측정하고 ${ }^{14,15)}$ 전후 두개골 영상 측정 시 발생하는 오차를 보정하기 위해 $\mathrm{LL} / \mathrm{RL}$ 을 계산하였다. 치료 시작 전 영상의학과에 의뢰해 전신 컷과 두부 정면, 정모를 측정하였고 마지막 치료 후 재방문해 같은 포맷으로 사진 촬영을 진행하였다 (Fig. 7).

\section{3) 동반 증상 평가}

비대칭으로 인한 동반 증상 호전 평가는 환자가 설문지에 증상의 불편감을 5점 리커트 척도로 직접 평가한 점수를 토대로 하였다. 


\section{4) 만족도 평가}

비대칭 개선의 만족도 평가는 설문지에 환자가 직 접 만족도를 5점 리커트 척도를 사용하여, 1점 (매우 불만족), 2점 (불만족), 3점 (보통), 4점 (만족), 5점 (매우 만족)으로 평가하였다. 동시에 만족/불만족 요 인에 대한 서술 내용도 조사하였다.

\section{증 례}

증례.

1. 성별/연령: 여자/ 만38세

2. 주소증: 양쪽 볼 꺼짐이 다르고 양쪽 눈 밑 꺼짐 정도가 다른 부분 때문에 피곤해 보인다는 말을 많이 들음

3. 내원일: 2018년 5월 28일

4. 현 병력:

10 년 전 치아교정 후 치아중심선의 틀어짐이 어느 정도 개선되었으나 출산 후 오른쪽으로 턱의 틀어짐 이 심해지면서 좌우 볼 살 꺼짐의 불균형, 입꼬리 비대 칭 등 연부조직의 불균형이 신경 쓰이는 상태라고 함.

\section{5. 초진 소견}

양쪽 어깨 높이가 다르고 정면을 보고 찍었지만 머 리가 정면을 향하고 있지 않음. 양쪽 눈썹, 눈의 위치
가 다르고 양쪽 광대뼈의 크기와 모양이 다르고 코가 휜 상태임. 입꼬리의 위치와 모양이 틀리고 양쪽 턱 의 크기와 모양이 다르고 아래 턱의 중심이 한쪽으로 틀어져 있음. 양쪽 광대에 붙은 살의 볼륨, 턱살의 볼륨 이 서로 다르고 눈 밑의 꺼진 정도가 서로 다른 상태임.

\section{6. 시술 내역(치료방법)}

교정기는 $\mathrm{ABA} 4$ 를 처방해서 매일 취침 전 착용하 도록 했고, 병원에 내원하도록 해 11 번의 치료를 진 행하는 동안 음양균형장치 제작과 경추 교정을 진행 하는 fcst 요법과 침 치료, CST pillow는 모두 진행 하였고 PBT 치료는 6회 진행되었고, 정골 요법은 3 회 시행되었다.

\section{7. 치료 결과}

1) 치료기간: 2018년 5월 28일 2018년 9월 5일 (총 11회 치료)

\section{2) 사진 평가}

(1) 일반사진평가

치료 후 얼굴의 중심인 미간과 상체의 중심인 쇄 골의 중심점이 일직선에 가깝게 놓이게 되었고 $(\mathrm{A}$ 와 $\mathrm{C}$ 각도 변화 $3 \rightarrow 1)$, 얼굴의 상부의 기준점인 미간의 중심점과 하부의 중심점인 턱의 중심부인 menton이

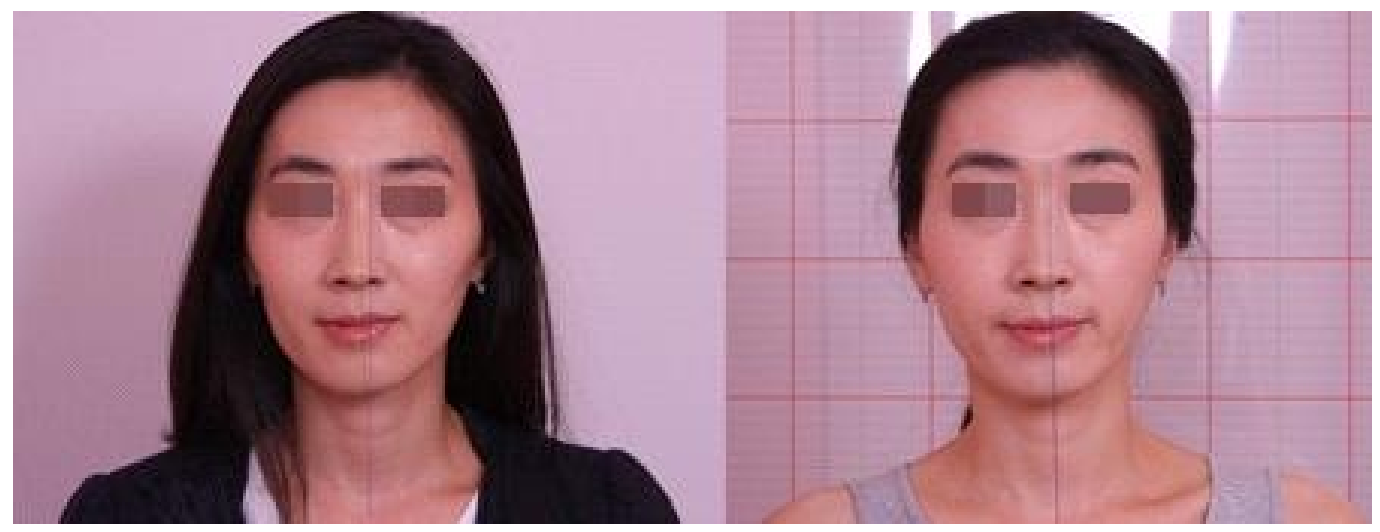

Fig. 8. Before and after photos of Case 1 
일직선상에 가까워져서 상악과 하악의 틀어짐이 개 선되었다 $(\mathrm{B}$ 와D 각도 변화 $4 \rightarrow 2)$. 또한 양쪽 눈의 기울어짐이 개선되었고 $(\mathrm{D}$ 와 수평선 각도 변화 1.5 $\rightarrow 1)$, 얼굴의 중심이 몸의 중심에 대해 균형 잡힌 상 태로 이동했다(Table 1).

Table 1. Angle before and after the procedure of Case 1

\begin{tabular}{lcc}
\hline & before & after \\
\hline Angle of A and C lines & 3 & 1 \\
Angle of B and C lines & 4 & 2 \\
Angle of D line and horizon & 1.5 & 1 \\
Angle of E line and horizon & 2 & 2 \\
\hline
\end{tabular}

(2) 두부 방사선 영상 평가

두부 정모 엑스레이 영상에서 $\mathrm{V}$ 선과 $\mathrm{M}$ 선이 이루 는 각도 차가 큰 것은 하악이 좌측이나 우측 특정 방 향으로 많이 틀어져 있음을 의미하고, $\mathrm{F}$ 선과 $\mathrm{H}$ 선이 이루는 각도 차가 큰 것은 상안모와 하안모의 틀어 짐이 큰 것을 의미한다. RR과 LL은 두개골의 정중 앙선에서 하악골의 좌우 최하연의 길이의 차이를 파 악하고자 함이다. 이 환자의 경우 우측으로 틀어진 정도가 개선되고( $\mathrm{V}$ 와 $\mathrm{M}$ 각도 $4 \rightarrow 2)$, 하안모의 틀어
짐의 편차가 개선되었다 $(\mathrm{F}$ 와H 각도 $2 \rightarrow 0.5)$. 또한 두개골 정중심선에서 좌우 턱의 길이가 대칭에 가깝 게 변했다고 평가할 수 있다(RL/LL $0.83 \rightarrow 0.99$ ). (Table 2) (Fig. 9)

Table 2. Angle before and after the procedure of Case 1

\begin{tabular}{lcc}
\hline & before & after \\
\hline Angle of $\mathrm{V}$ and $\mathrm{M}$ lines & 4 & 2 \\
Angle of F line and H line & 2 & 0.5 \\
RL/LL & $5.13 / 6.18,0.83$ & $5.77 / 5.8,0.99$ \\
\hline
\end{tabular}

(3) 척추 방사선 영상 분석 (Fig. 10)

3) 동반 증상 변화

말을 오래하면 생기는 턱관절 부근 통증은 $(2 \rightarrow 0)$, 입을 열고 닫을 때 나는 소리 $(3 \rightarrow 2)$ 는 호전되었다. 만성적인 편두통의 빈도가 주 2회에 발생하던 것이 치료받는 4 개월간 총 2 회정도 발생하는 것으로 호전 되었다. 또한 두통의 통증의 강도가 vas $5 \rightarrow \mathrm{vas} 2$ 로 줄었고, 거의 하루 종일 지속되던 두통은 진통제를 먹어야 진정되는 정도였으나 진통제를 복용하지 않 고도 30 분 정도 짧은 시간 나타났다. 뒷목이 당기고

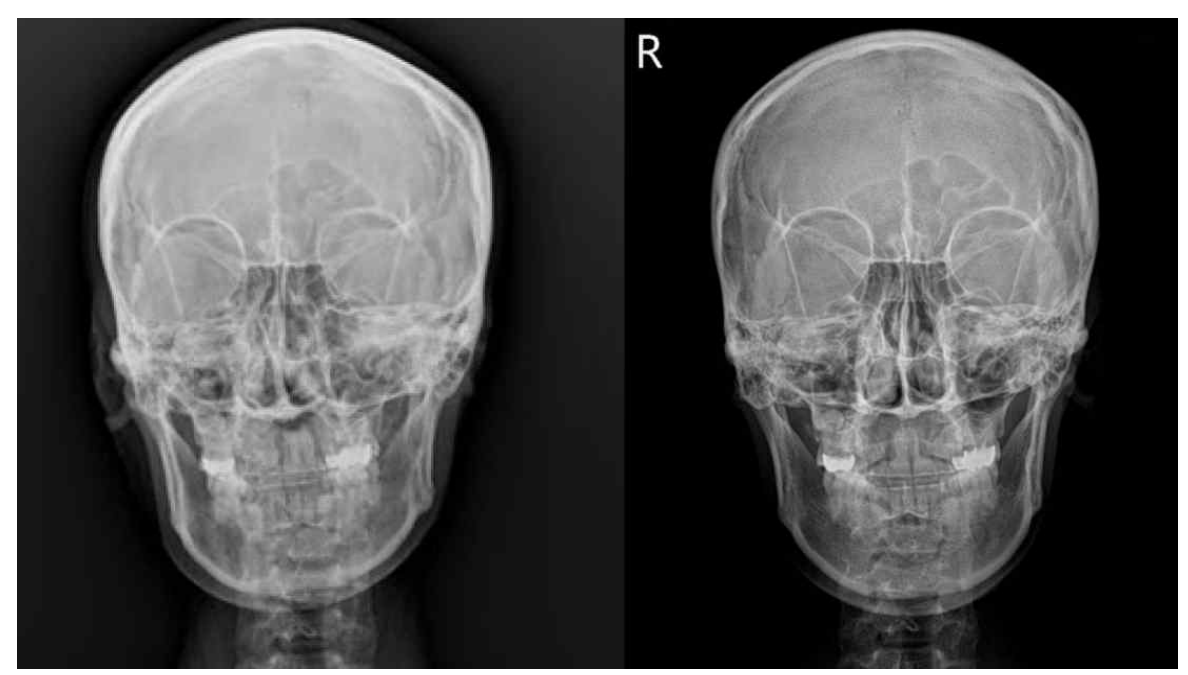

Fig. 9. Before and after radiograms of Case 1 

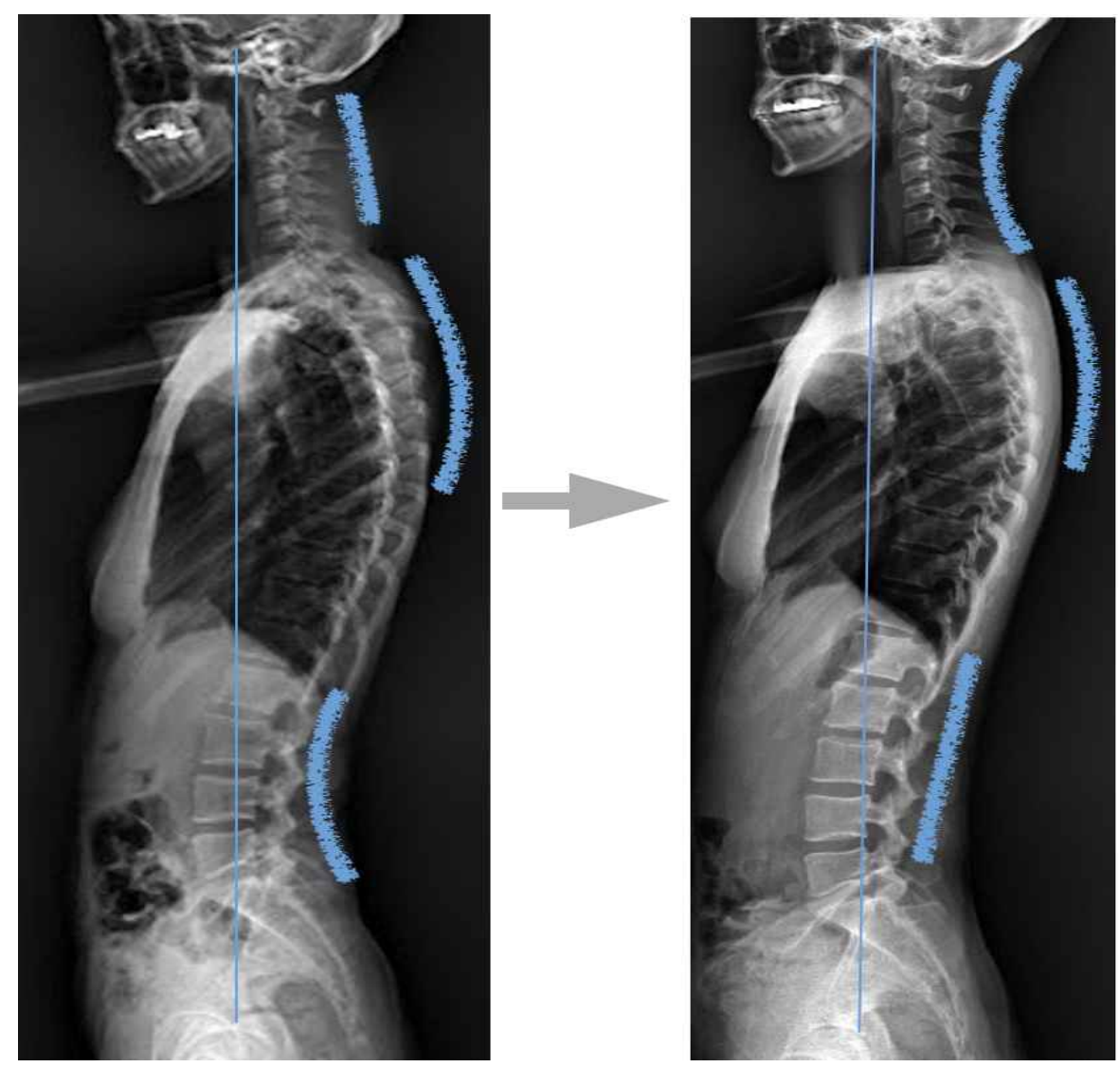

Fig. 10. Before and after body radiograms of Case 1

1. The curve of the cervical spine was changed to a $\mathrm{C}$ curve after correction 2. The degree of thoracic kyphosis and lumbar lordosis improved

뺏뺏하고 항상 무거운 증상 $(4 \rightarrow 3)$, 어깨와 팔이 무겁 고 저린 증상 $(3 \rightarrow 2)$ 이 좋아졌다. 귀에서 소리가 나는 증상 $(3 \rightarrow 2)$, 한쪽 귀가 진공 상태처럼 멍한 느낌 $(4 \rightarrow$ 2), 현기증 빈도 $(4 \rightarrow 1)$ 로 호전되었다. 머리가 한쪽으 로 기우는 느낌이 들던 증상 $(3 \rightarrow 0)$, 몸이 한쪽으로 기우는 느낌 $(2 \rightarrow 1)$, 의자에 앉아 있으면 불편해서 자 세를 자꾸 바꾸게 되는 현상 $(4 \rightarrow 3)$ 도 줄어들었다.

4) 주관적만족도평가

- $5 / 5$

- 개선 되었다고 생각되는 부분: 좌우 턱 사이즈,

\section{광대 크기나 위치}

- 불만족 요인: 없음

증례 2 .

1. 성별/연령: 남자/ 만23세

2. 주소증: 좌우 턱 사이즈가 차이 나는 것과 양쪽 광 대 크기도 다름

3. 내원일: 2019년 1월 22일

4. 현병력: 모델 지망생으로 카메라 테스트를 할 기 회가 많은데 안면비대칭 때문에 사진을 찍었을 때 좌우 모습이 너무 다름 


\section{5. 초진 소견:}

양쪽 어깨 높이가 다르다. 머리 위치가 중심에서 벗어나 있다. 정면을 보고 찍었지만 머리가 정면을 향하고 있지 않다. 양쪽 눈썹, 눈의 위치가 다르다. 양쪽 광대뼈의 크기와 모양이 다르다. 코가 휘었다. 양쪽 입꼬리의 위치와 모양이 틀리다. 양쪽 턱의 크 기와 모양이 다르고 아래턱의 중심이 한쪽으로 틀어 져 있고 아래턱이 앞으로 튀어 나와 있다. 양쪽 광대 에 붙은 살의 볼륨, 볼살의 볼륨, 턱살의 볼륨이 서 로 다르다. 양쪽 눈가 주름의 깊이나 길이, 눈밑의 꺼진 정도가 서로 다른 상태이며 양쪽 팔자 주름의 깊이나 길이나 서로 다른 상태를 호소하였다.

\section{6. 시술내역(치료방법)}

$\mathrm{ABA} 5$ 를 처방해서 매일 취침전 착용해 아침까지 7-8시간 정도 물고 있도록 지시했고, 병원에 내원하 도록 해 12 번의 치료를 진행하는 동안 음양균형장치 제작과 경추교정을 진행하는 fcst 요법과 침치료는 cst pillow는 모두 진행하였다. 2회차부터 11회차는 $\mathrm{PBT}$ 를 진행했고, 정골요법은 4회 진행했다.
7. 치료경과

1) 치료기간

2018년 10월 20일 2018년 1월 22일 (총13회 치료)

2) 사진평가

(1) 일반사진평가

치료 후 얼굴의 중심인 미간과 상체의 중심인 쇄 골의 중심점이 일직선에 가깝게 놓이게 되었고 $(\mathrm{A}$ 와 $\mathrm{C}$ 각도 변화 $3 \rightarrow 1)$, 상악과 하악의 틀어짐은 원래 없 던 상태였고(B와 D 각도 0$)$. 또한 양쪽 눈의 기울어 짐이 개선되었고 $(\mathrm{D}$ 와 수평선 각도 변화 $3 \rightarrow 1)$, 양쪽 입꼬리의 기울어짐도 개선되었다. (E와 수평선 각도 변화 4->1.5) (Table 3)

Table 3. Angle before and after the procedure of Case 2

\begin{tabular}{lcc}
\hline & before & after \\
\hline Angle of A and C lines & 3 & 1 \\
Angle of B and C lines & 0 & 0 \\
Angle of D line and horizon & 3 & 1 \\
Angle of E line and horizon & 4 & 1.5 \\
\hline
\end{tabular}

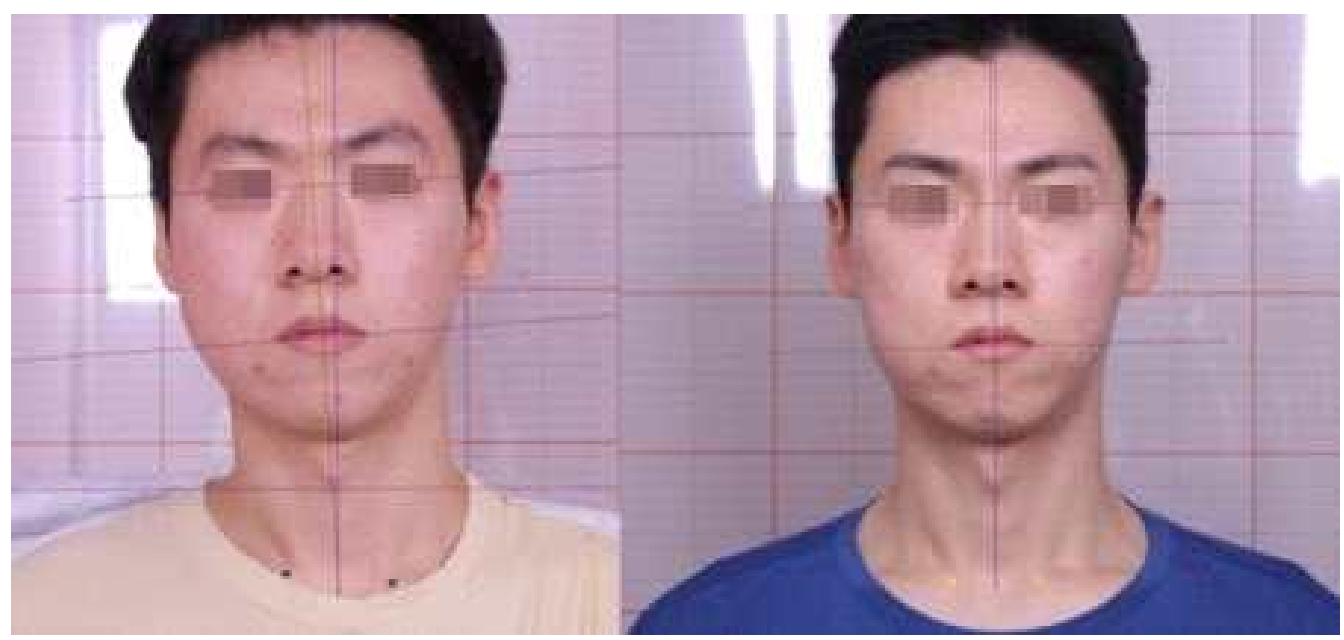

Fig. 11. Before and after photos of Case 2 


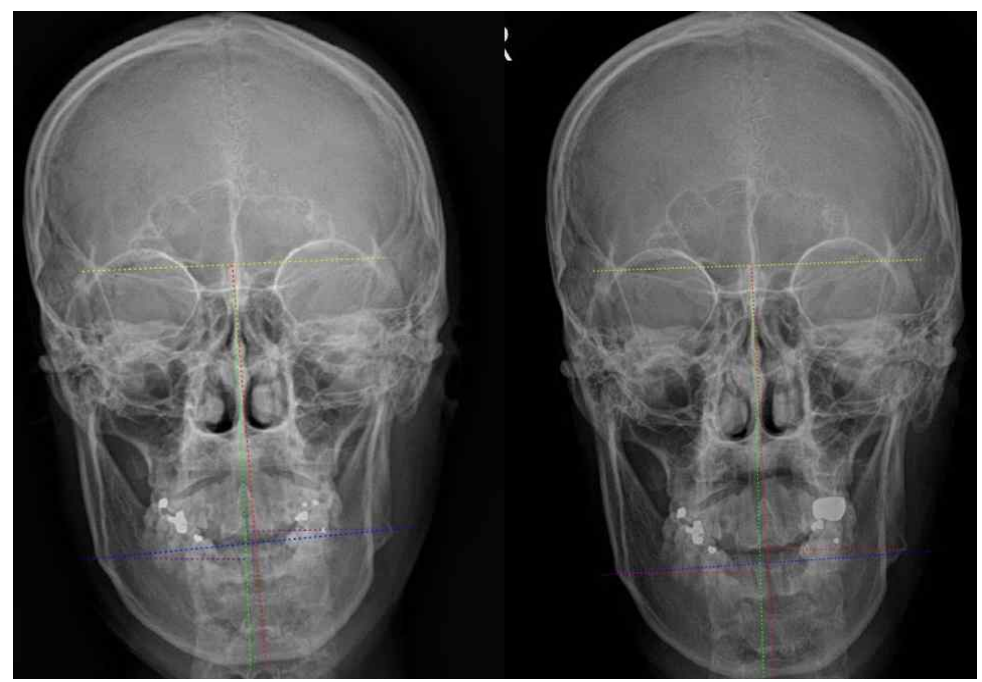

Fig. 12. Before and after radiograms of Case 2

(2) 두부 방사선 영상 평가

두부 정모 엑스레이 영상에서 $\mathrm{V}$ 선과 $\mathrm{M}$ 선이 이루 는 각도 차가 큰 것은 하악이 좌측이나 우측 특정 방 향으로 많이 틀어져 있음을 의미하고, $\mathrm{F}$ 선과 $\mathrm{H}$ 선이 이루는 각도 차가 큰 것은 상안모와 하안모의 틀어 짐이 큰 것을 의미한다. $\mathrm{RR}$ 과 $\mathrm{LL}$ 은 두개골의 정중 앙선에서 하악골의 좌우 최하연의 길이의 차이를 파 악하고자 함이다. 이 환자의 경우 우측으로 틀어진 정도가 개선되고 $(\mathrm{V}$ 와 $\mathrm{M}$ 각도 $2 \rightarrow 1)$ 하안모의 틀어짐 의 편차가 개선되었다 $(\mathrm{F}$ 와H 각도 $2.5 \rightarrow 1)$. 또한 두개 골 정중심선에서 좌우 턱의 길이 차는 원래 크지 않 았다(RL/LL 1.01 $\rightarrow 0.99)$. (Fig. 12) (Table 4)

Table 4 . Angle before and after the procedure of Case 2

\begin{tabular}{lcc}
\hline & before & after \\
\hline Angle of $\mathrm{V}$ and $\mathrm{M}$ lines & 2 & 1 \\
Angle of F line and H line & 2.5 & 1 \\
RL/LL & $8.04 / 7.94,=1.01$ & $6.9 / 6.96,=0.99$ \\
\hline
\end{tabular}

(3) 턱관절 영상 분석

이 케이스에서 측면 두부 엑스레이 영상에서 치료
전후에 하악과두의 위치 변화와 치아의 위치 이동으 로 아래턱의 위치의 변화를 시각적으로 확인할 수 있다. 오른쪽 하악과두의 위치는 후방으로 이동했고 왼쪽 하악과두의 위치는 상방으로 이동했다.(Fig. 13)

\section{(4) 척추 방사선 영상 분석}

첫번째 증례와 같이 척추 만곡이 생리적 만곡에 가깝게 바뀌는 것이 2 번째 증례에서도 확인이 가능 하다. 첫번째 증례의 측면 전신 영상에서 변화가 보 인 반면, 두번째 환자는 전면부 엑스레이 전신 영상 에서 흉추, 요추의 측만 양상의 만곡이 정상 만곡에 가깝게 변화된 것이 시각적으로 관찰된다(Fig. 14).

\section{4) 동반 증상 변화}

뒷목이 당기고 뻣뻣하고 항상 무거운 느낌 $(3 \rightarrow 0)$ 허리가 무겁고 아픔 $(3 \rightarrow 0)$, 귀에서 소리가 나는 이명 현상 $(2 \rightarrow 0)$, 현기증 $(2 \rightarrow 1)$ 머리가 한쪽으로 기우는 느낌 $(4 \rightarrow 1)$, 몸이 한쪽으로 기우는 느낌 $(3 \rightarrow 1)$, 의 자에 앉으면 불편해서 자세를 자꾸 바꾸던 패턴 $(3 \rightarrow$ $2)$, 배가 과도하게 나오거나 등이 굽은 느낌 $(3 \rightarrow 0)$ 으 로 호전되었다. 
(524) Journal of Korean Medicine 2019;40(3)

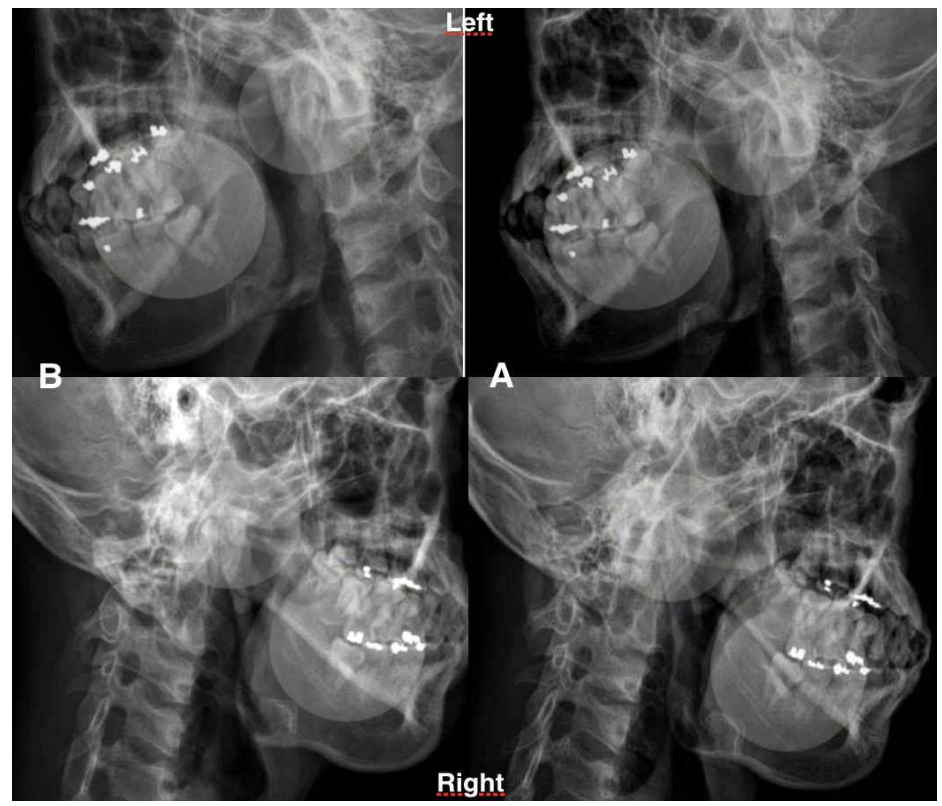

Fig. 13. Before and after right \& left lateral radiograms of Case 2

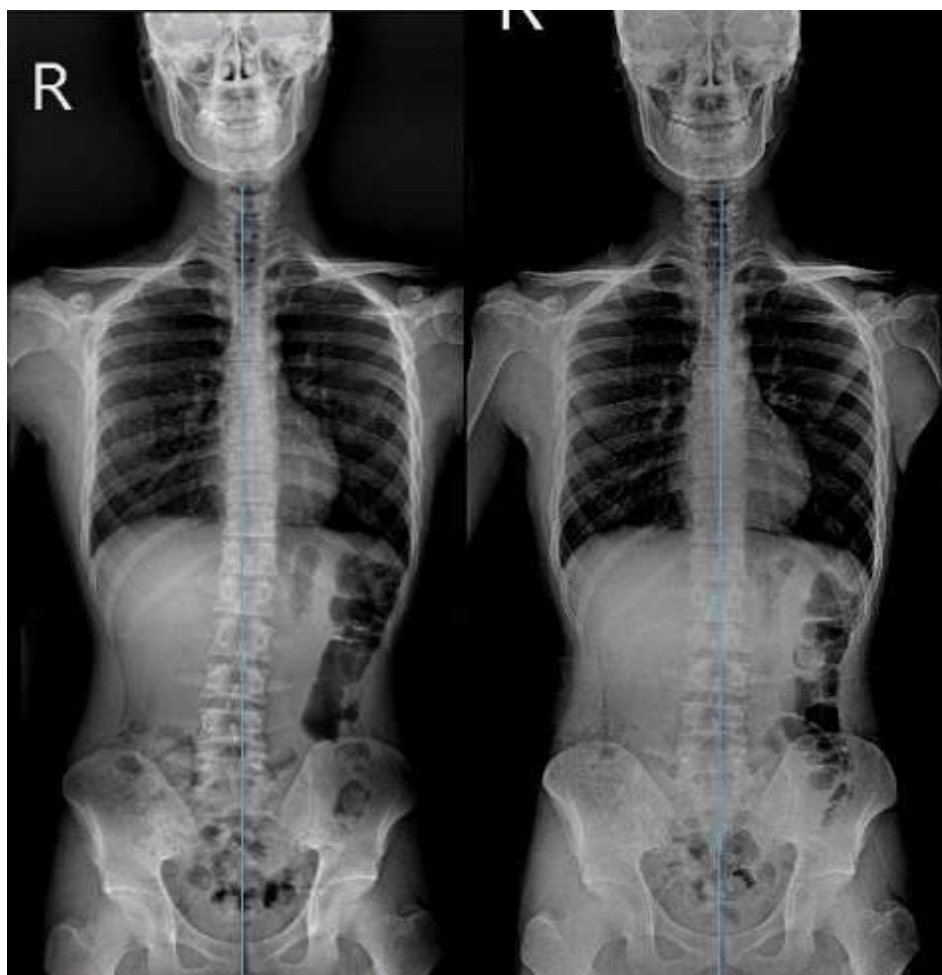

Fig. 14. Before and after body radiograms of Case 2 
5) 만족도, 부작용 평가

\section{- $4 / 5$}

- 개선되었다고 생각되는 부분: 눈썹 위치와 이마 모양, 눈 크기나 위치, 입꼬리 위치, 턱음 개선, 턱관절 안면 통증 개선, 어깨통증, 두통과 같은 증상들

- 불만족 요인: 없다.

\section{증례 3 .}

1, 성별/연령: 여자/ 만32세

2. 주소증: 좌우 눈높이가 맞지 않고 좌우 광대 크기 와 모양이 다름

3. 내원일: 2019년 1월 21일

4. 현병력: 얼굴이 오른쪽으로 돌아가 있는 상태, 정 면을 보고 사진을 찍어도 턱이 오른쪽으로 돌아 가 있다.

\section{5. 초진 소견:}

양쪽 어깨 높이가 다르다. 정면을 보고 찍었지만 머리가 정면을 향하고 있지 않다. 양쪽 눈의 위치가 다르다. 양쪽 광대뼈의 크기와 모양이 다르다. 양쪽 입꼬리의 위치가 다르다. 아래턱의 중심이 한쪽으로
틀어져 있다. 양쪽 볼 살의 볼륨이 서로 다르다. 양 쪽 턱살의 볼륨이 서로 다르다. 양쪽 눈 밑이 꺼진 정도가 서로 다르다. 양쪽 팔자 주름의 깊이나 길이 가 서로 다르다.

\section{6. 시술 내역(치료 방법)}

$\mathrm{ABA} 4$ 를 처방해서 매일 취침 전 착용해 아침까지 7-8시간 정도 물고 있도록 지시했고, 병원에 내원하 도록 해 12 번의 치료를 진행하는 동안 음양균형 장 치 제작과 경추 교정을 진행하는 FCST 요법과 침 치료, CST pillow는 모두 진행하였고 2회차부터 11 회차는 $\mathrm{PBT}$ 를 진행했고, $\mathrm{CST}$ pillow는 총 5회 진행 했고, 정골 요법은 3회 진행되었다.

\section{7. 치료 경과}

\section{1) 치료 기간}

2019년 1월 21일 2019년 4월 15일 (총 13회 치료)

2) 사진 평가

(1) 일반사진평가

세번째 증례의 경우 치료 후 얼굴의 중심인 미간

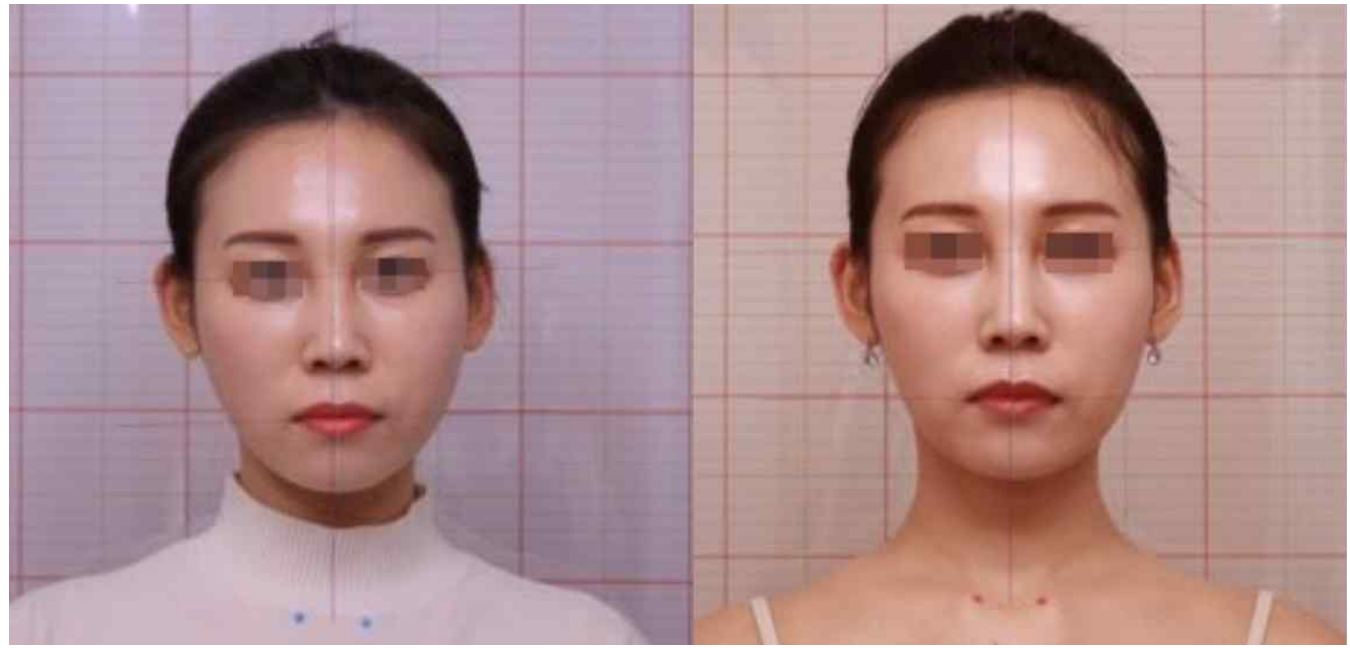

Fig. 15. Before and after photos of Case 3 
과 상체의 중심인 쇄골의 중심점이 일직선에 가깝게 놓이게 되었고 $(\mathrm{A}$ 와 $\mathrm{C}$ 각도 변화 $1 \rightarrow 0)$, 미간과 menton의 틀어짐도 개선되었고 $(\mathrm{B}$ 와 $\mathrm{C}$ 가 이루는 각 도 2à1). 또한 양쪽 눈의 기울어짐이 개선되었고(D 와 수평선 각도 변화 $2.5 \rightarrow 0.5)$, 양쪽 입꼬리의 기울 어짐도 개선되었다. $(\mathrm{E}$ 와 수평선 각도 변화 $2 \rightarrow 0.5$ )

(Table 5)

Table 5. Angle before and after the procedure of Case 3

\begin{tabular}{lcc}
\hline & before & after \\
\hline Angle of A and C lines & 1 & 0 \\
Angle of B and C lines & 2 & 1 \\
Angle of D line and horizon & 2.5 & 0.5 \\
Angle of E line and horizon & 2 & 0.5 \\
\hline
\end{tabular}

(2) 두부 방사선 영상 평가

두부 정모 엑스레이 영상에서 $\mathrm{V}$ 선과 $\mathrm{M}$ 선이 이루 는 각도 차가 큰 것은 하악이 좌측이나 우측 특정 방 향으로 많이 틀어져 있음을 의미하고, $\mathrm{F}$ 선과 $\mathrm{H}$ 선이 이루는 각도 차가 큰 것은 상안모와 하안모의 틀어 짐이 큰 것을 의미한다. RR과 LL은 두개골의 정중 앙선에서 하악골의 좌우 최하연의 길이의 차이를 파
악하고자 함이다. 이 환자의 경우 우측으로 틀어진 정도가 개선되고 $(\mathrm{V}$ 와 $\mathrm{M}$ 각도 $3 \rightarrow 1)$ 하안모의 틀어 짐의 편차가 개선되었다 $(\mathrm{F}$ 와 $\mathrm{H}$ 각도 $1 \rightarrow 0)$. 또한 두 개골 정중심선에서 좌우 턱의 길이가 대칭에 가깝게 변 했다고 평가할 수 있다(RL/LL 0.86 $\longrightarrow 0.99$ ) (Table 6).

Table 6. Angle before and after the procedure of Case 3

\begin{tabular}{lcc}
\hline & before & after \\
\hline Angle of V and M lines & 3 & 1 \\
Angle of F line and H line & 1 & 0 \\
RL/LL & $4.48 / 5.16,0.86$ & $5.01 / 5.02,0.99$ \\
\hline
\end{tabular}

(3) 척추 방사선 영상 분석

2 번 증례처럼 3 번 증례의 경우도 전면 엑스레이 영상에서 척추 만곡에서 요추부와 흉추부의 좌측 측 만 증상이 시각적으로 호전되는 변화가 관찰된다. 치 료 전에는 흉추는 오른쪽으로 요추부는 왼쪽으로 휘 어져 있으나 치료 후 일직선에 가까운 척추 위치로 이동한 것이 육안으로 확인된다(Fig. 17).

3) 동반 증상 변화

말을 오래하면 턱관절 부근에 생기던 통증 $(2 \rightarrow 0)$,

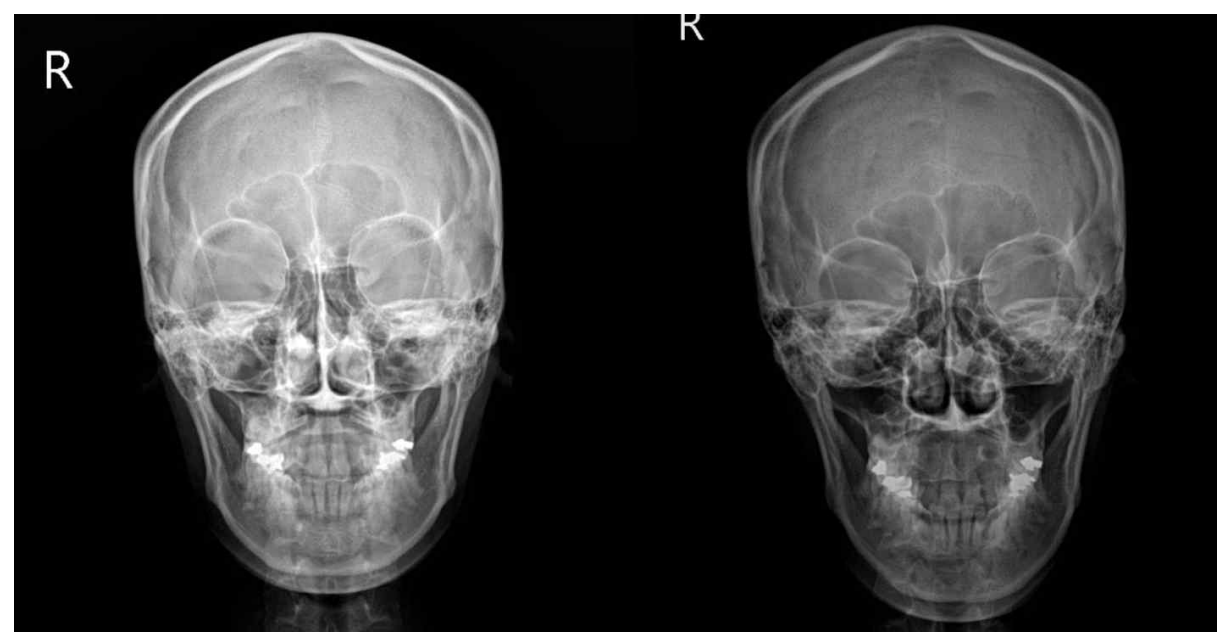

Fig. 16. Before and after radiograms of Case 3 


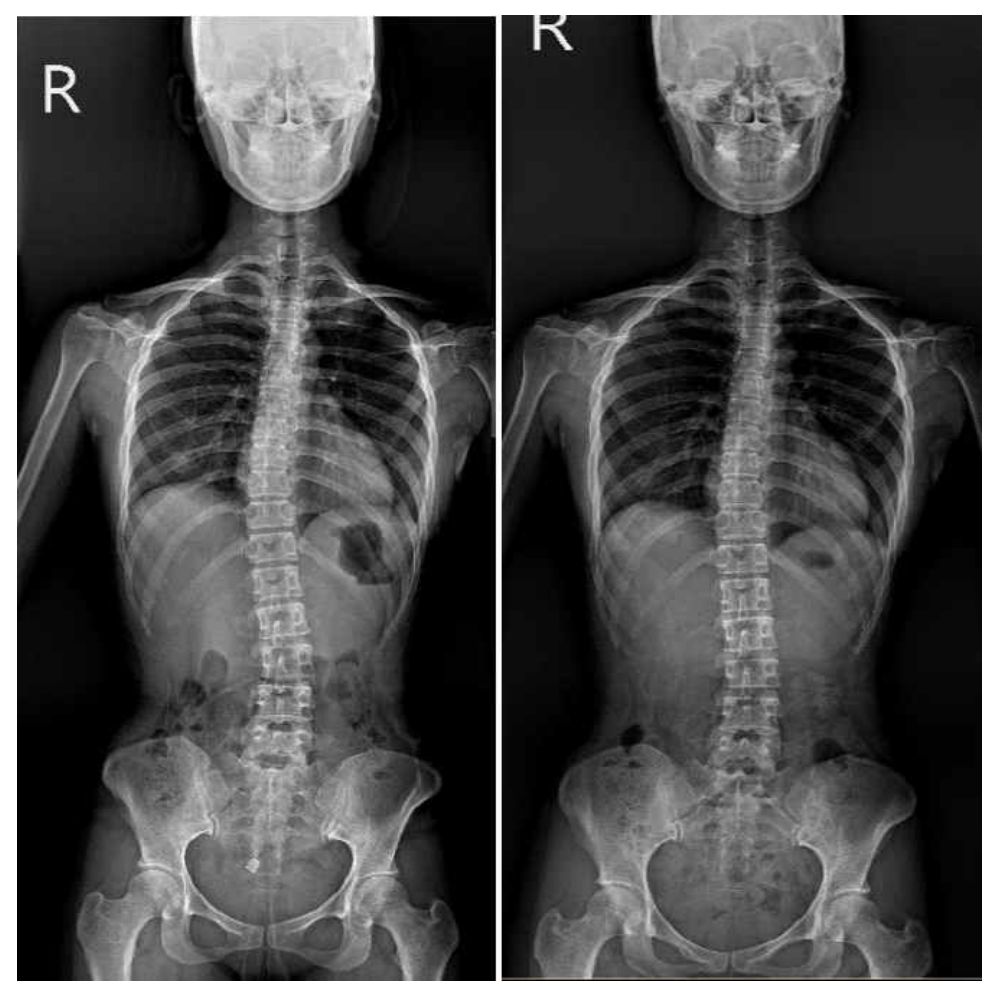

Fig. 17. Before and after body radiograms of Case 3

입을 열고 닫을 때 나는 소리 $(1 \rightarrow 0)$, 턱과 얼굴의 근 육이 뻐근하고 통증이 느껴지는 통증 $(2 \rightarrow 0)$ 이 호전 되었다. 단단한 음식을 먹지 않아도 턱 주변이 아팠 는데 호전되었고 $(3 \rightarrow 0)$ 뒷목이 당기고 뺏뺏하고 항상 무거웠는데 좋아졌다 $(3 \rightarrow 0)$ 등이 결리고 불편했던 증상도 좋아졌다 $(2 \rightarrow 0)$ 엉덩이와 허벅지가 불편하고 당기는 증상 $(2 \rightarrow 0)$ 한쪽 귀가 아플 증상 $(4 \rightarrow 1)$, 눈이 쉽게 충혈되는 증상 $(4 \rightarrow 3)$ 이 호전되었다.

\section{4) 주관적 만족도 평가}

- $5 / 5$

- 개선되었다고 생각되는 부분: 턱 모양과 사이즈, 광대 크기나 위치, 어깨 통증, 두통과 같은 다른 증상들

- 불만족 요인: 없다.
증례 4 .

1. 성별/연령: 여자/ 만28세

2. 주소증: 아래턱이 오른쪽으로 돌아가 있고 양쪽 눈높이와 광대 높이가 다름

3. 내원일: 2019년 1월 22일

4. 현병력: 아무리 노력해도 얼굴을 중앙에 둘 수가 없고 자꾸 오른쪽으로 틀어진다. 양쪽 눈높이 차 이가 너무 나서 신경쓰인다.

5. 초진 소견:

양쪽 어깨 높이가 다르다. 머리 위치가 중심에서 벗어나 있다. 정면을 보고 찍었지만 머리가 정면을 향하고 있지 않다. 양쪽 눈썹의 위치가 다르다. 양쪽 눈의 위치가 다르다. 양쪽 광대뼈의 크기와 모양이 다르다. 코가 휘었다. 양쪽 입꼬리의 위치가 다르다. 아래턱의 중심이 한쪽으로 틀어져 있다. 광대에 붙은 


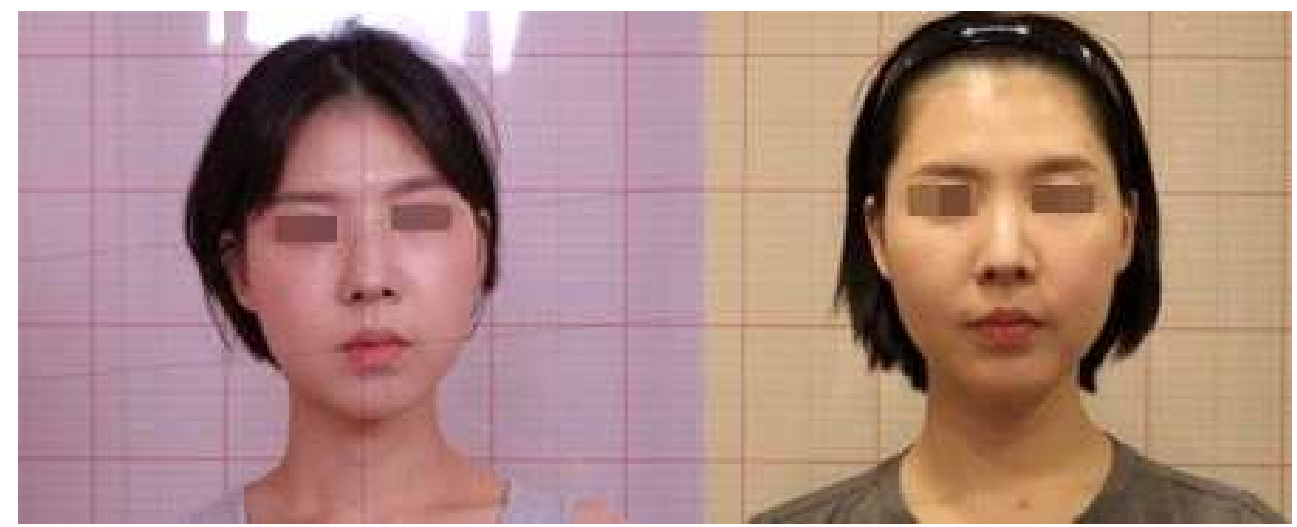

Fig. 18. Before and after photos of Case 4

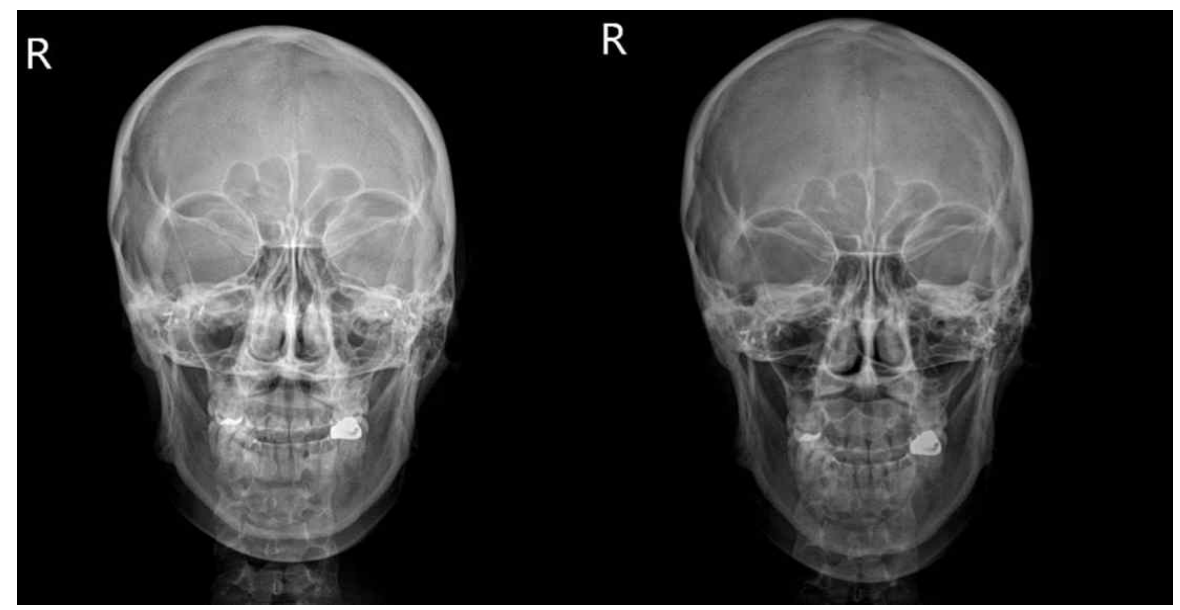

Fig. 19. Before and after radiograms of Case 4

살의 볼륨이 양쪽이 서로 다르다. 양쪽 볼 살의 볼륨 이 서로 다르다. 양쪽 눈 밑의 꺼진 정도가 다르다.

\section{6. 시술 내역(치료 방법)}

$\mathrm{ABA} 4$ 를 처방해서 매일 취침 전 착용해 아침까 지 7-8시간 정도 물고 있도록 지시했고, 병원에 내원 하도록 해 14 번의 치료를 진행하는 동안 음양균형장 치 제작과 경추 교정을 진행하는 FCST 요법과 침치 료, CST pillow는 모두 진행하였고 2회차부터 2 회 4차, 6 14회는 PBT를 진행했고, cst pillow는 총 7회 진행했고, 정골 요법은 6회 진행했다.

\section{7. 치료 경과}

1) 치료기간

2018년 9월 14일 2018년 12월 26일 (총14회 치료)

2) 사진 평가

(1) 일반사진평가

네번째 증례의 경우 치료 후 얼굴의 중심인 미간 과 상체의 중심인 쇄골의 중심점이 일직선에 가깝게 놓이게 되었고 $(\mathrm{A}$ 와 $\mathrm{C}$ 각도 변화 $3 \rightarrow 0.5)$, 미간과 menton의 틀어짐도 개선되었고 $(\mathrm{B}$ 와 $\mathrm{C}$ 가 이루는 각 도 3.5à1.5). 또한 양쪽 눈의 기울어짐이 개선되었고 


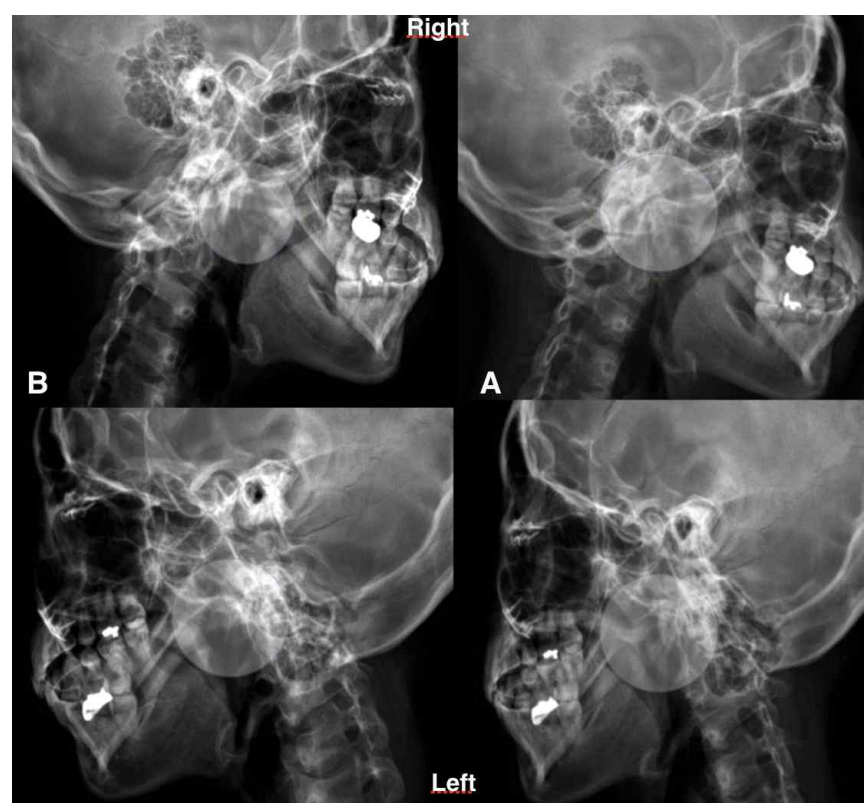

Fig. 20. Before and after left lateral radiograms of Case 3

$(\mathrm{D}$ 와 수평선 각도 변화 $4 \rightarrow 2$ ), 양쪽 입꼬리의 기울어 짐도 개선되었다. (E와 수평선 각도 변화 $6 \rightarrow 1.5$ )

\section{(Table 7)}

Table 7. Angle before and after the procedure of Case 4

\begin{tabular}{lcc}
\hline & Before & after \\
\hline Angle of A and C lines & 3 & 0.5 \\
Angle of B and C lines & 3.5 & 1.5 \\
Angle of D line and horizon & 4 & 2 \\
Angle of E line and horizon & 6 & 1.5 \\
\hline
\end{tabular}

(2) 두부 방사선 영상 평가

두부 정모 엑스레이 영상에서 $\mathrm{V}$ 선과 $\mathrm{M}$ 선이 이루 는 각도 차가 큰 것은 하악이 좌측이나 우측 특정 방 향으로 많이 틀어져 있음을 의미하고, $\mathrm{F}$ 선과 $\mathrm{H}$ 선이 이루는 각도 차가 큰 것은 상안모와 하안모의 틀어 짐이 큰 것을 의미한다. RR과 LL은 두개골의 정중 앙선에서 하악골의 좌우 최하연의 길이의 차이를 파 악하고자 함이다. 이 환자의 경우 우측으로 틀어진 정도가 개선되고 $(\mathrm{V}$ 와 $\mathrm{M}$ 각도 $3 \rightarrow 0)$ 하안모의 틀어
짐의 편차가 개선되었다 $(\mathrm{F}$ 와 $\mathrm{H}$ 각도 $1.5 \rightarrow 0.5)$. 또한 두개골 정중심선에서 좌우 턱의 길이차도 약간 변했 다.(RL/LL 0.94 $\rightarrow 0.95$ ) (Table 8)

Table 8 . Angle before and after the procedure of Case 4

\begin{tabular}{lcc}
\hline & before & after \\
\hline Angle of $\mathrm{V}$ and $\mathrm{M}$ lines & 3 & 0 \\
Angle of $\mathrm{F}$ line and $\mathrm{H}$ line & 1.5 & 0.5 \\
$\mathrm{RL} / \mathrm{LL}$ & $7.1 / 7.51,0.94$ & $6.01 / 6.27,0.95$ \\
\hline
\end{tabular}

(3) 턱관절 영상 분석

이 증례에서도 2 번 증례와 마찬가지로 오른쪽 측 면 두부 엑스레이 영상에서 치료 전후에 하악과두의 위치 변화와 치아의 위치 이동으로 아래턱의 위치의 변화를 시각적으로 확인할 수 있다. 하악과두의 위치 는 전방으로 이동했고 아래 대구치의 위치도 전방으 로 동시에 이동한 것이 확인된다.(Fig. 20)

(4) 척추 방사선 영상 분석

위의 2,3번 증례외마찬가지로 4 번 증례도 요추부 

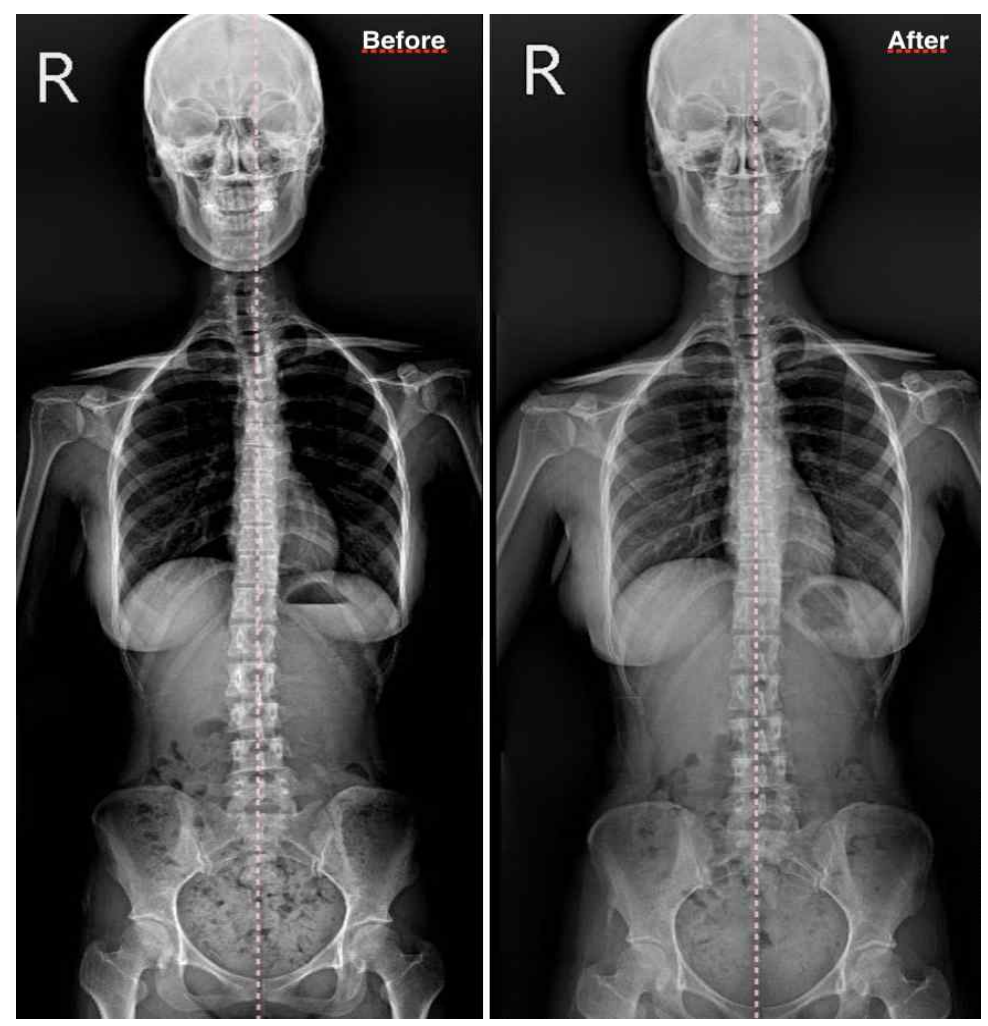

Fig. 21. Before and after body radiograms of Case 4

의 우측 만곡 현상이 개선되고 머리의 위치가 척추 중심에 가깝게 변화된 것이 육안상 관찰된다.

\section{3) 동반 증상 변화}

턱과 얼굴의 피부 감각이 무딘 느낌 $(2 \rightarrow 1)$, 턱이 빠지거나 느슨한 느낌 $(4 \rightarrow 2)$, 입을 열고 닫을 때 나 는 소리는 오른쪽 $(5 \rightarrow 3)$, 왼쪽 $(3 \rightarrow 0)$ 로 좋아졌다. 아 침에 일어나면 느껴지던 턱관절에 통증이나 불편감 $(5 \rightarrow 1)$, 입을 벌리기 힘든 경우가 발생하는 빈도도 호전되었다 $(4 \rightarrow 1)$. 뒷목이 당기고 뻣뻣하고 항상 무 거웠던 증상 $(3 \rightarrow 2)$, 등이 결리고 불편했던 증상 $(2 \rightarrow$ $1)$, 어깨나 팔이 무겁고 저린 증상 $(2 \rightarrow 1)$, 밝은 곳에 서 눈이 지나치게 부시고 시린 증상 $(4 \rightarrow 2)$, 눈이 쉽 게 충혈되는 증상 $(5 \rightarrow 3)$, 코콜이 증상 $(3 \rightarrow 1)$ 로 호전 되었다.
(1) 주관적 만족도 평가

- $4 / 5$

- 개선되었다고 생각되는 부분: 좌우 턱 사이즈, 광대 크기나 위치, 휜 코, 턱 음 개선

- 불만족 요인: 눈과 눈썹 위치 개선이 부족하다.

증례 5 .

1. 성별/연령: 여자/ 만28세

2. 주소증: 한쪽 턱이 크고 그쪽으로 살이 계속 붙는 느낌이 있음

3. 내원일: 2019년 1월 22일

4. 현병력: 사진을 찍었을 때 좌우 턱, 광대 위치, 눈 썹 위치가 모두 틀린 것이 신경쓰인다.

5. 초진 소견:

양쪽 광대, 볼 살, 턱살의 붙은 살의 볼륨이 서로 


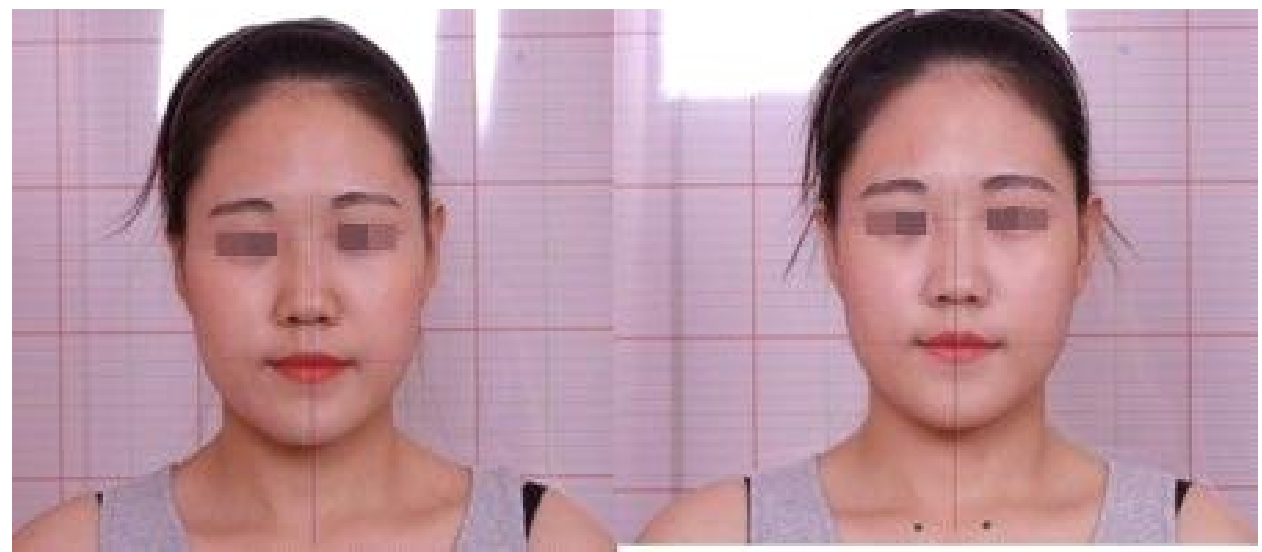

Fig. 22. Before and after photos of Case 5

다른 것이 관찰된다. 양쪽 눈 밑의 꺼진 정도가 서로 다르다.

\section{6. 시술 내역(치료방법)}

$\mathrm{ABA} 4$ 를 처방해서 매일 취침 전 착용해 아침까지 7-8시간 정도 물고 있도록 지시했고, 병원에 내원하 도록 해 10 번의 치료를 진행하는 동안 음양 균형 장 치 제작과 경추 교정을 진행하는 fcst 요법과 침 치 료, cst pillow는 모두 진행하였고 2회차부터 2회 10 회는 PBT를 진행했고, cst pillow는 총 5회 진행했 고, 정골요법은 3 회 진행했다.

\section{7. 치료 경과}

1) 치료기간

2018년 8월 21일 2018년 10월 17일 (총10회 치료)

\section{2) 사진 평가}

\section{(1) 일반 사진 평가}

다섯번째 증례의 경우 치료 후 얼굴의 중심인 미 간과 상체의 중심인 쇄골의 중심점이 일직선에 가깝 게 놓이게 되었고 $(\mathrm{A}$ 와 $\mathrm{C}$ 각도 변화 $2.5 \rightarrow 1)$, 미간과 menton의 틀어짐도 개선되었고(B와 $\mathrm{C}$ 가 이루는 각 도 3àl). 또한 양쪽 눈의 기울어짐이 개선되었고( $\mathrm{D}$ 와
수평선 각도 변화 $5 \rightarrow 2$ ), 양쪽 입꼬리의 기울어짐도 개선되었다.(E와 수평선 각도 변화 $1.5 \rightarrow 1$ ) (Fig. 22)

\section{(Table 9)}

Table 9. Angle before and after the procedure of Case 5

\begin{tabular}{lcc}
\hline & before & after \\
\hline Angle of A and C lines & 2.5 & 1 \\
Angle of B and C lines & 3 & 1 \\
Angle of D line and horizon & 5 & 2 \\
Angle of E line and horizon & 1.5 & 1 \\
\hline
\end{tabular}

(2) 두부 방사선 영상 평가

두부 정모 엑스레이 영상에서 $\mathrm{V}$ 선과 $\mathrm{M}$ 선이 이루 는 각도 차가 큰 것은 하악이 좌측이나 우측 특정 방 향으로 많이 틀어져 있음을 의미하고, $\mathrm{F}$ 선과 $\mathrm{H}$ 선이 이루는 각도 차가 큰 것은 상안모와 하안모의 틀어 짐이 큰 것을 의미한다. RR과 $\mathrm{LL}$ 은 두개골의 정중 앙선에서 하악골의 좌우 최하연의 길이의 차이를 파 악하고자 함이다. 이 환자의 경우 우측으로 틀어진 정도가 개선되고 $(\mathrm{V}$ 와 $\mathrm{M}$ 각도 $2 \rightarrow 0.5)$ 하안모의 틀 어짐의 편차가 개선되었다 $(\mathrm{F}$ 와 $\mathrm{H}$ 각도 $2 \rightarrow 0)$. 또한 두개골 정중심선에서 좌우 턱의 길이가 대칭에 가깝 게 변했다고 평가할 수 있다(RL/LL $1.04 \rightarrow 1.00$ ). (Table 10) 


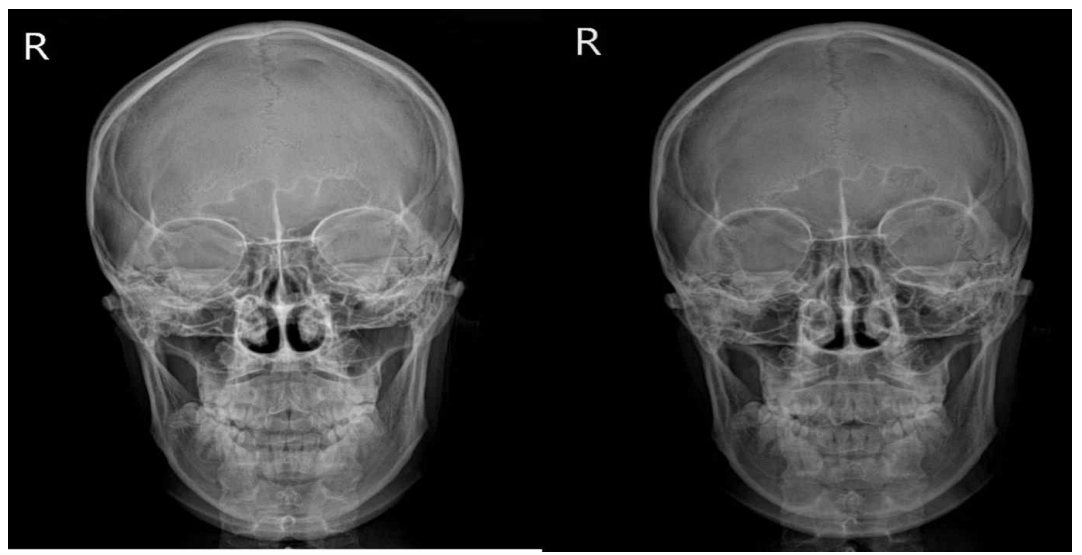

Fig. 23. Before and after radiograms of Case 5
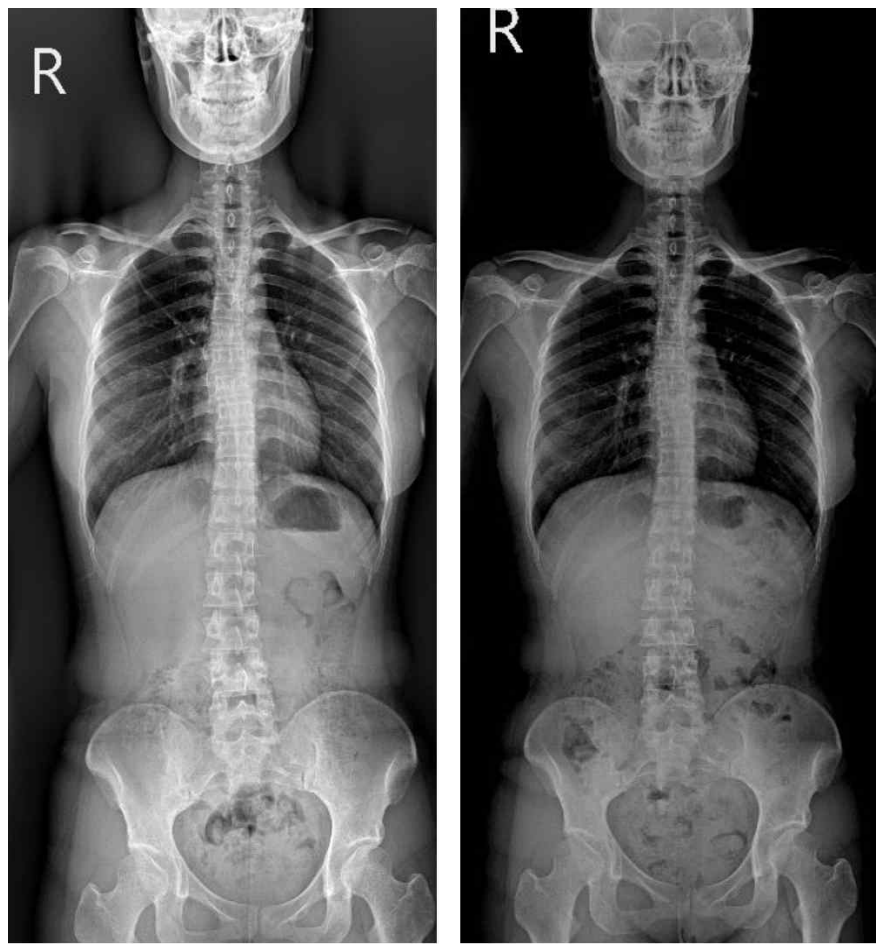

Fig. 24. Before and after body radiograms of Case 5

Table 10. Angle before and after the procedure of Case 5

\begin{tabular}{lcc}
\hline & before & after \\
\hline Angle of $\mathrm{V}$ and $\mathrm{M}$ lines & 2 & 0.5 \\
Angle of $\mathrm{F}$ line and $\mathrm{H}$ line & 2 & 0 \\
$\mathrm{RL} / \mathrm{LL}$ & $5.63 / 5.40,1.04$ & $5.83 / 5.82,1.00$ \\
\hline
\end{tabular}

(3) 척추 방사선 영상 분석(Fig. 24)

3) 동반증상변화

입을 열고 닫을 때 왼쪽 턱에서 나는 소리 $(3 \rightarrow 2)$, 말을 많이 하면 턱에서 생기는 통증 $(3 \rightarrow 2)$, 턱이 빠 
Table 11. The changes of Mean value and Correction effect

\begin{tabular}{|c|c|c|c|c|c|c|c|c|}
\hline & & \multicolumn{4}{|c|}{ Photograph } & \multicolumn{3}{|c|}{ X-ray } \\
\hline & & A-C & B-C & D-horizon & E-horizon & V-M & F-H & RL/LL \\
\hline \multirow{2}{*}{$\begin{array}{l}\text { Mean value } \\
(\text { mean } \pm \text { SD) }\end{array}$} & before & $2.5 \pm 0.86$ & $2.5 \pm 1.58$ & $3.2 \pm 1.35$ & $3.1 \pm 1.88$ & $2.8 \pm 0.83$ & $1.8 \pm 0.57$ & $0.93 \pm 0.09$ \\
\hline & after & $0.7 \pm 0.44$ & $1.1 \pm 0.74$ & $1.3 \pm 0.67$ & $1.5 \pm 0.93$ & $0.9 \pm 0.74$ & $0.4 \pm 0.41$ & $0.98 \pm 0.01$ \\
\hline $\begin{array}{l}\text { Correction effect } \\
(\text { mean } \pm \mathrm{SD})\end{array}$ & & $1.8 \pm 0.57$ & $1.4 \pm 0.89$ & $1.9 \pm 0.89$ & $1.6 \pm 2.07$ & $1.9 \pm 0.67$ & $1.4 \pm 0.41$ & \\
\hline
\end{tabular}

지거나 느슨한 느낌 $(3 \rightarrow 2)$, 턱과 얼굴의 근육이 뻐근 하고 통증이 느껴지던 부분 $(5 \rightarrow 2)$ 부드러운 음식을 먹어도 턱이 아픔 $(2 \rightarrow 0)$ 두통과 편두통이 주 2 회정 도 발생해 지속 시간이 종일 유지되고 진통제를 먹 어야만 진정이 되었는데 치료 후 주 1 회 정도로 2-3 시간 지속되다 사라지는 경우가 많고 진통제 안 먹 어도 진정되는 정도로 호전되었다. 뒷목이 당기거나 뺏뺏해 항상 무거움 $(5 \rightarrow 3)$,어깨와 팔이 늘 무겁고 저 림 $(5 \rightarrow 0)$, 등이 결리고 불편 $(5 \rightarrow 3)$, 허리통증 $(5 \rightarrow 3)$ 눈이 쉽게 충혈되고 눈이 자꾸 침침함 $(5 \rightarrow 0)$, 한쪽 귀가 멍해지는 증상 $(5 \rightarrow 1)$, 귀에서 나는 이명 현상 $(5$ $\rightarrow 2)$. 현기증 $(5 \rightarrow 2)$, 이갈이와 코골이의 정도와 빈도
$(5 \rightarrow 2)$. 자각적으로 머리나 몸이 한쪽으로 기우는 느 낌 $(5 \rightarrow 3)$ 으로 호전되었다. 의자에 앉아있으면 불편해 자세를 자꾸 바꾸던 습관 $(3 \rightarrow 2)$, 배가 자꾸 앞으로 나오고 등이 굽은 느낌 $(5 \rightarrow 0)$ 으로 좋아졌다.

\section{(1) 주관적만족도평가}

- $5 / 5$

- 개선되었다고 생각되는 부분: 좌우 턱 사이즈, 광대 크기나 위치, 어깨 통증과 두통과 같은 증 상들

- 불만족 요인: 없다.

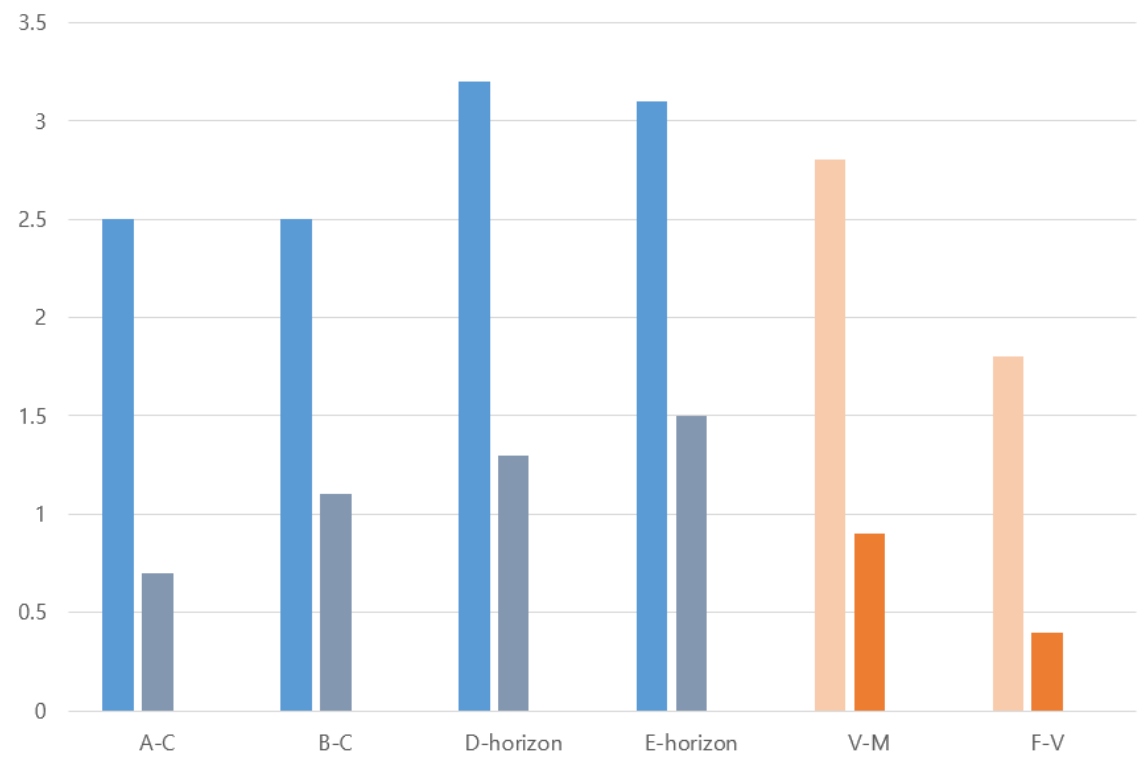

Fig. 25. The changes of angles between lines 


\section{고 찰}

안면비대칭은 두개의 안면정중선을 기준으로 상악 이나 하악의 중심이 좌측이나 우측으로 편위되어 있 거나 안면의 높이와 넓이의 좌우 차이가 있는 경우 를 의미한다 ${ }^{16)}$. 정모 두부 방사선 사진의 계측 항목 과 안면비대칭의 상관관계를 연구한 여러 연구나 안 면비대칭과 하악의 연관성에 대한 연구를 보면 두개 안면부의 비대칭은 주로 하악안면부에서 기인하며, mention의 편위가 안면비대칭을 인지하게 되는 가장 중요한 요소로 알려져 있다 ${ }^{17,18)}$.

안면비대칭 원인에 따른 분류는 매우 다양하다. Ericson과 Waite의 분류를 Plint와 Ellisdon의 분류 와 Cheong과 Lo의 분류와 종합하면 임신, 출산 시 발생한 선천적인 원인, 반안면왜소증, 다발성 신경섬 유종증과 같은 유전적인 요인으로 인한 선천성 비대 칭과 외상과 감염증, 종양 등에 의해 발생한 후천적 비대칭과 교합 간섭, 습관 등 치아적 원인과 그리고 형성부전증이나 하악과두 과형성과 같은 발육성 비
대칭으로 구분해 볼 수 있다 ${ }^{1920)}$. 또한 Choi와 Baek 에 따르면 해부학적인 기준에 따라 안면비대칭의 분 류는 치아 치조성 비대칭, 골격성비대칭, 근육성비대 칭, 연조직성비대칭, 기능성 비대칭으로 나눌 수도 있다 ${ }^{21)}$ (Table 12, 13).

그러나 같은 원인으로 발생한 안면비대칭이라도 근육의 보상 능력, 성장기 발육 양상에 따라 개인차 가 있을 수 있다 ${ }^{22}$. 안면골의 성장은 10 대 성장기에 급격하게 진행되고, 특히 하악의 성장은 만 17세까지 진행되기 때문에 머리의 다른 부분의 성장보다 장기 간에 걸쳐 이뤄지고 하악과두 돌기는 특히 성장 중 에 다양한 편측성, 양측성 장애를 일으킬 수 있는 환 경적 영향과 유전적 영향에 의해 변하기가 쉽다. ${ }^{23)}$ 그래서 하악과두 성장 장애는 비대칭한 성장을 일으 키고 이로 인해 하악의 편측 과발육이나 미발육에 의한 안면비대칭이 발생할 수 있다 ${ }^{24)}$. Choi와 Baek 에 따르면 해부학적으로는 치아 치조 문제나 골격의 문제, 연조직의 문제나, TMJ(TemporoMadibular joint)의 문제 중 1 개나 2개 이상 연관이 되어 안면비

Table 12. Facial Asymmetry Classification 1

\begin{tabular}{lll}
\hline Congenital & Acquied & Developmental \\
\hline cleft lip and palate & temporomandibular joint ankylosis & - agenesis \\
Tessier facial cleft & facial trauma & - hypoplasia \\
hemifacial microsomia & childhood radiotherapy & - unilateral condylar hyoerplasia \\
neurofibromatosis & fibrous dysplasia & - prognathism deviation \\
Congenital torticollis & facial tumors & - bilateral deviation of narrow maxilla(adenoid face ) \\
craniosynostosis & Parry-Romberg syndrome & - Maxillary narrowing by amorphrous soft tissue \\
vascular disorder & condylar fracture & movement (ex.finger sucking, abmomal \\
prefatal intrauterine damage & degenerative TMJ disease & swallowing) \\
& & - crossbite and malposition of tooth \\
\hline
\end{tabular}

Table 13. Facial Asymmetry Classification 2

\begin{tabular}{|c|c|c|c|c|}
\hline Tooth alveolar & Skeletal & Muscular & Soft tissue & Fuctional \\
\hline $\begin{array}{l}\text { Premature loss } \\
\text { Of infant teeth } \\
\text { Congenital tooth defect } \\
\text { Common habits such as } \\
\text { thumb sucking } \\
\text { accuracy deficit in gene } \\
\text { expression }\end{array}$ & $\begin{array}{l}\text { hemifacial microsomia } \\
\text { Genetic factors such as } \\
\text { multiple } \\
\text { neurofibromatosis } \\
\text { damage at birth by } \\
\text { pressure } \\
\text { unilateral damage during } \\
\text { osteosarcoma }\end{array}$ & $\begin{array}{l}\text { - muscle atropy by } \\
\text { hemifacial microsomia } \\
\text { and cerebral palsy muscle } \\
\text { - difference sich as } \\
\text { massester hypertropy } \\
\text { - abnormal muscle } \\
\text { - case missed treatment of } \\
\text { SCM fibrosos in torticollis }\end{array}$ & $\begin{array}{l}\text { Surplus of tissue } \\
\text { by osteotomy } \\
\text { Unilateral } \\
\text { softtissue } \\
\text { enlargement }\end{array}$ & $\begin{array}{l}\text { lateral,anterior and posterior } \\
\text { deflection of mandible } \\
\text { transverse stenosis of } \\
\text { maxillary inverted teeth } \\
\text { TMJ disorder with } \\
\text { displacement of articular } \\
\text { disk }\end{array}$ \\
\hline
\end{tabular}


대칭이 발생할 수 있다고도 한다 ${ }^{25)}$. 그러나 실제로 안면비대칭의 정확한 원인에 대한 연구는 아직 부족 한 실정이다.

어느 정도의 안면비대칭은 누구나 가지고 있고 대 부분의 경우 이를 치료의 대상으로 인식하는 사람이 많지 않았다. 그러나 최근에는 경미한 정도로 치료를 고려할만큼 안면비대칭에 대한 관심도가 높아졌다. 경미한 안면비대칭은 상대적인 비대칭, 준임상적인 비대칭(subclinical asymmetry)이나 일반적인 비대칭 을 의미하며 이 분류에는 안와나 코와 상순의 위치 나 미소를 지었을 때 입술의 움직임, 상악, 하악 정 중선, 개구의 하악의 변이, 좌우주름이나 보조개의 위치 차이 등을 포함한다 ${ }^{26)}$.

일반적으로 안면비대칭의 평가는 정모의 두부 방 사선 사진을 이용해 기준점을 설정해 거리와 각도를 계측한 수치를 좌우 비교해 경조직의 정량적 평가를 진행하는 연구가 보편적이었으나 Michaels과Tourne, Yogosawa는 골격의 형태 이상이 근육이나 피부 연 부 조직에 가려질 수 있어서 연조직 분석 필요성을 강조했다 ${ }^{27}$. 또한 $\mathrm{dslr}$ 로 촬영된 사진을 이용한 안면 비대칭 교정 치료로 연조직의 변화를 확인한 연구가 2017년에 진행이 되었지만 경조직의 분석이 빠진 연 구였다 ${ }^{28)}$

본 연구에서는 안면비대칭을 평가하기 위해서 경 조직 분석을 위해 두부 방사선 사진을 이용했고 연 조직에 의해 완화된 비대칭의 정도를 동시에 평가하 기 위해 $\mathrm{dslr}$ 카메라로 촬영된 안모 사진을 동시에 분석해 정량화 하는데 활용했다. 비수술적 안면비대 칭 교정 치료의 결과를 확인하기 위해 연조직과 경 조직 모두 정량화하기 위해 연조직에서는 하악의 위 치 변위를 파악하기 위한 선과 몸을 기준으로 얼굴 의 위치 변위와 좌우 눈의 기울기, 입술의 기울기를 정량적으로 측정하였고 그 결과 평균적으로 $\mathrm{A}$ 와 $\mathrm{C}$ 간의 각도차로 파악해 본 교정 효과는 $1.8 \pm 0.57, \mathrm{~B}$ 와 $\mathrm{C}$ 의 각도차로 파악해 본 교정 효과는 $1.4 \pm 0.89, \mathrm{D}$ 와 수평면 간의 각도차는 $1.9 \pm 0.89, \mathrm{E}$ 와 수평면 간의 각
도 차이는 $1.9 \pm 0.89$ 를 보였다. $\mathrm{A}$ 와 $\mathrm{C}$ 간의 각도차이 가 줄어든 결과는 몸의 중심점에서 편측으로 틀어진 머리 위치가 중심으로 이동되었음을 의미하고, $\mathrm{B}$ 와 $\mathrm{C}$ 사이의 각도차가 줄어든 것은 하악을 기준으로 상 악의 틀어짐이 회복되었음을 의미한다. 경조직에서는 두개골의 기준으로 수치를 측정하였는데 두개골의 틀어짐은 평균적으로 $1.9 \pm 0.67$, 하안모의 틀어짐은 $1.4 \pm 0.41$ 의 교정 효과를 보였다(Table 11) (Fig 25). 비수술적 한의 치료로 개선이 가능한 비대칭의 종 류는 가역적인 조직의 변화가 가능한 일부 근육의 비대칭, 연조직의 비대칭, 기능성 비대칭 3 가지로 볼 수 있다. 본 연구는 비수술적인 안면비대칭 치료가 이러한 안면비대칭의 개선에 효과가 있음을 확인하 고자 한 증례이다. 비수술적 안면비대칭 교정 치료는 한방 치료법인 안면골의 움직임을 주도하는 근육의 경결점을 이완해 주는 침자극 치료, 중심위에서의 비 정상적인 교두 접촉으로 인해 하악이 측방이나 전후 방으로 편향되는 현상을 교정하기 위해 음양균형장 치 제작과 표준형 균형 장치인 $\mathrm{ABA}$ 를 동시에 처방 해 8시간 착용하도록 하였다. 한 연구에 따르면 $\mathrm{ABA}$ 는 턱관절 장애 환자의 통증을 경감시키는데 유 의미한 효과가 있는 것으로 알려져 있다 ${ }^{29)}$. PBT를 이용한 골반 교정이 결합된 FCST 요법, 경추의 위치 를 교정하는 경추 추나, 근막을 이완하는 정골요법, 바른 자세를 잡아주는 자세교정 습관을 갖도록 하는 행동교정 요법으로 구성된다. 서술된 여러 치료방법 을 본 증례의 5 명의 환자에게 $10 \sim 14$ 회의 치료를 진 행하는 동안 반복적으로 진행했다. 음양 균형 장치는 FCST (기능적 뇌척주 요법)에서 인체의 음양 균형을 정상화하기 위해 활용하는 장치로 교합측정지를 여 러 장 겹쳐서 양쪽 어금니로 물게 해서 두면 체간의 자세에 대한 3 가지 불균형 요인이 이상적으로 회복 되는 하악의 위치를 파악해 제작한다. FCST에서는 인체 음양 불균형을 턱관절로 파악 가능하며 턱관절 에 대한 교정을 통해 인체의 균형을 찾을 수 있다고 보고 있다. 또한 FCST는 턱관절의 중심 균형뿐 아니 
라 경추와 전신 척추를 정상 위치로 회복시켜 전신 균형을 맞춰준다고 보고 있다잉ㅎㅇㅇㅇ골의 첨부에 안면 부의 중심이 미간의 직선에 놓이게 하고 하악의 위 치를 상안모의 중심인 미간중심점과 일직선에 놓이 도록 해서 전신의균형을 도모하는 것이 비수술적인 안면비대칭 교정 치료의 목표이다. 안면부에 국한된 교정에 그치지 않고 전신의 비대칭, 턱관절 장애와 같이 안면비대칭의 진행에 영향을 주는 요인들까지 같이 교정하는 것이다.

5 가지 증례의 환자 모두 하악과두의 위치 이동으 로 인한 턱 통증, 턱 관절음, 개구 범위 제한 등의 증 상을 일부 또는 전체를 가지고 있어 턱관절 장애가 의심된다. 증례 2,4 에서 측면 엑스레이 영상에서 하 악과두의 위치가 이동한 것으로 육안상 확인할 수 있고 또한 치료 후 각각의 턱관절 장애로 인해 느끼 던 주관적인 증상이 호전되었다. 하악과두 위치 이동 이 환자가 초진시 호소하던 턱 통증이나 턱에는 나 는 소리가 치료 후 주관적으로 개선되는 것과 관련 이 있는지, 턱관절 장애로 인한 여타 증상을 개선하 는 효과가 연관이 있는지는 더 깊은 연구가 필요할 것으로 보인다.

턱관절 장애를 가진 환자에게 안면비대칭이 동반 되어 있는 경우가 많다는 연구는 국내외에서 여러 건 진행되어 왔다 ${ }^{31,32)}$. M. INUI의 연구에 따르면 턱 관절 장애와 안면비대칭은 밀접한 관계가 있으며 Jang의 연구에서는 안면비대칭은 하악의 변위와 관 련이 깊고 이 경우 교합의 부조화에 의한 하악의 비 정상적인 폐구 현상이 동반된다고 보았다 ${ }^{32)}$. FCST 에서는 턱관절 장애가 있는 경우 음양 균형 편차가 발생할 수 있고 경추 중 상부 경추인 축추에서 아탈 구가 발생하여 척추의 정렬이 틀어지면서 전신 척추 체계의 균형이 깨지게 되고 이 경우 턱관절의 음양 균형을 조절해 환추와 축추를 정상화하면 연쇄적으 로 전신 척추를 바로잡을 수 있다고 보고 있다 ${ }^{33)}$. 턱 관절의 균형은 하악골 전면 정중점을 기준으로 상하 전후 좌우의 방향의 위치 변화를 말하며 척추의 자
세를 중심으로 한 두면부와 체간의 자세에 대한 3 가 지 요소는 상초, 중초, 하초의 요인의 자세 변화가 인체의 음양 균형에 영향을 주게 되어 그 결과가 턱 관절에 반영된 것으로 보고 있다 ${ }^{34}$. 위의 5 명의 케이 스 모두 시각적으로 안면 구조물 위치 변화와 함께 척추 만곡의 변화까지 같이 호전되는 결과를 보인다. 안면비대칭의 발생이 전신 척추 구조나 자세와 관련 성이 있다는 연구는 일부 진행되어 있다 ${ }^{35)}$.

안면비대칭을 가지고 있는 환자들의 경우 턱끝점 의 변위가 발생하며, 또한 얼굴의 회전을 보상하려는 방향으로 natural head position (NHP) 위치가 기울 어지는 경향이 있고 ${ }^{30}$, 또한 얼굴의 변위를 보상하기 위해 척추가 휘는 방향에 영향을 주기 때문에 안면 비대칭과 척추측만증은 동반되는 빈도가 높다는 연 구결과도 있으며 척추측만증을 포함한 몸의 불균형 한 자세는 부정 교합과 악안면 이상 발달에 영향을 줄 수 있으며 두경부의 자세와 체위와 안면골의 형 태 사이에 상호연관성이 깊다는 보고도 있닥). 또한 척추측만증이 있는 경우 몸의 비대칭, 어깨의비대칭, 다리길이 차이 등의 증상이 나타날 수 있고 이러한 요인은 치아 교합에 영향을 주고 안면의 성장과 안 면의 변형에 영향을 줄 수 있다고 알려져 있다 ${ }^{38)}$. 또 한 FCST를 이용해 한의학적 치료로 경추 정렬을 개 선하는 효과를 영상의학적으로 분석한 연구도 있다 39).

본 연구의 5 건의 증례의 치료에 활용된 FCST 요 법은 턱관절에 대한 4가지 음양 균형과 전신 자세에 서 반영되는 3 가지 음양 균형으로 인체의 균형을 조 절한다. 비수술적 안면비대칭 교정 치료는 전신의 위 치를 고려해서 얼굴의 위치를 교정하는 것을 원칙으 로 하기 때문에 얼굴 교정을 진행함과 동시에 경추 와 골반 위치를 교정하는 자극을 병행하게 되는데, 전신 척추의 만곡이 개선되는 것이 골반 교정과 자 세교정하는 치료때문인지 안면부와 턱관절의 위치 교정의 결과인지는 이 연구에서 확인하는 것은 어렵 다. 차후 더 많은 연구가 필요해 보인다. 
수술로 안면비 대칭 정도를 개선한 연구나 하악골 의 변이가 안면비대칭과 관련이 크다는 치과적 연구 는 많이 있으나 다양한 비수술적인 치료 방법을 이 용해 안면비대칭을 개선했다는 질 높은 증례 연구는 부족하다. 본 연구는 엑스레이 영상을 활용해 한의학 적 안면비대칭 치료가 안면부의 연조직뿐 아니라 경 조직의 변화, 전신의 척추 만곡에도 교정 효과가 있 음을 보여준 보다 잘 설계된 연구라는 의미가 있다.

본 연구는 두부 방사선 사진이나 정면 사진을 통 한 안면비대칭 분석이다. 3 차원으로 입체적인 두개 악안면 골격을 2 차원적 평면화한 영상을 활용하기 때문에 좌우 또는 전후방에 위치한 구조물의 확대율 차이로 인한 왜곡 현상이 발생할 가능성이 있어서 안면비대칭에 대한 평가가 부정확할 가능성이 있다. 향후 3 차원 영상을 이용한 안면비대칭 연구를 진행 할 필요가 있어 보인다. 또한 본 연구는 5 개의 증례 만을 이용한 연구로 더 정확한 연구를 위해 많은 모 수의 증례를 이용한 연구를 진행하여 통계적 유의성 을 검토하는 작업도 필요할 것으로 보인다. 비수술적 인 치료나 치아 교정 없이 교정 가능한 안면비대칭 의 유형에 대한 보다 많은 케이스 분석이 요구되며 또한 전신 자세와 안면비대칭의 관련성에 대한 평가 는 시각적인 부분에 그친 한계가 있기 때문에 향후 다른 연구를 통해 계측을 통해 안면비대칭과 척추측 만증과 일자목과 같은 척추 불균형의 관련성을 평가 하는 것이 필요하다.

\section{결 론}

안면비대칭 교정 치료에 대한 일반적인 연구는 외 과적 요법이나 치아 교정에 제한되어 있다. 그러나 안면비대칭의 종류 중 수술적 치료를 적용할 수 없 는 근육성 비대칭, 연부 조직성 비대칭, 기능성 비대 칭에 대한 연구는 오히려 부족하다. 이번 증례 연구 를 통해 이러한 종류의 비대칭의 경우 가역적이며 보존적인 침, 추나 수기 치료, FCST 등의 다양한 한
의학적 복합 치료로 교정할 수 있다는 가능성을 확 인할 수 있었다. 이 치료를 통해 상안모와 하안모가 이루는 각도, 양쪽 눈의 기울어짐, 양쪽 입꼬리의 기 울어짐이 개선되는 교정 효과를 일반 사진과 두개골 영상에서 확인할 수 있었다. 또한 한의학적 안면비대 칭 교정 치료의 경우 전신의 균형을 고려해 턱관절 의 상하좌우전후 편차를 바로 잡아 하악의 틀어짐을 개선하고 근막을 이완을 유도해 안면골의 위치를 교 정하는 개념이다. 이 과정을 통해 전신의 불균형으로 발생한 다양한 신체 증상을 동시에 호전시키는 것을 목적으로 한다. 이 또한 전신 엑스레이 영상을 통해 확인할 수 있었다. 그러나 상기 치료 중 한가지 치료 가 효과를 낸 것인지 복합적인 치료가 효과적인지는 다른 연구를 통해 확인이 필요하다. 또한 안면비대칭 과 척추측만증이나 경추통 등과 전신 척추 증상의 관련성도 보다 더 깊은 연구를 통해 개연성을 확인 하는 것이 필요해 보인다.

\section{참고문헌}

1. Petti M.Pirttiniemi. Associations of mandibular and facial asymmetries. American Journal of Orthodontics Orthopedia (1994) p191

2. 김왕식 외 2 인. 안면비대칭자의 3 차원전단단층 사진분석에서경,연조직간의비대칭정도차이. 대 한치과교정학회지 (2005) p163, 169

3. Guilheme Thiesen 외 2인. Facial Asymmetry: Current review. Dental Press J Ortho(2015) $111 \mathrm{p}$

4. Cheng \& Lo. Facial Asymmetry: Etiology, Evaluation and Management. Chang Gung $\operatorname{Med}(2011)$

5. Guilheme Thiesen 외 2인. Facial Asymmetry: Current review. Dental Press J Ortho(2015)

6. 윤일선 외 1 인. 군집분석법에 의한 안면비대칭 분류. 대한치과의사협회지 (2001) 
7. 박지영. 안면비대칭과 척추측만증의 관계 연구. 서울대학교치의학대학원 (2015)

8. 서연주 외 9인. 기능적 뇌척주 요법을 병행한 한방치료가 턱관절장애가 있는 교통사고 환자에 미치는 영향. 대한침구의학회지(2016) p.15

9. 인창식 외 4인. 침구 경락음양론의 새로운 발전, 기능적 뇌척주 요법 (FCST). 대한 경락경혈학회 지(2005)

10. 권찬영 외 2 인. 안면비대칭에 대한 한의학적 치 료 효과: 증례보고. 대한침구학회지 (2017) p.182

11. 서연주 외 9 인. 기능적 뇌척주요법을 병행한 한 방치료가 턱관절장애가 있는 교통사고 환자에 미치는 영향. 대한침구의학회지(2016) p.15

12. Torsten Liem. Cranial Osteopathy principle and practice (2004) p.401 p.404

13. 권찬영 외 2 인. 안면비대칭에 대한 한의학적 치 료효과: 증례보고. 대한침구학회지 (2017)

14. 윤일선 외 1 인. 군집분석법에 의한 안면비대칭 분류. 대한치과의사협회지 (2001) p.767

15. 장영일. FACIAL ASYMMETRY. 대한치과교 정학회지 (1991) p.255

16. 김왕식 외 2 인. 안면비대칭자의 3 차원 전단 단 층 사진 분석에서 경,연조직 간의 비대칭 정도 차이. 대한치과교정학회지 (2005) p.163

17. Petti M.Pirttiniemi. Associations of mandibular and facial asymmetries. American Journal of Orthodontics Orthopedia (1994)

18. M.INUI외 1인. Facial asymmetry in temporomandibular joint disorders. Journal of Rehabilitation(1999)

19. Guilheme Thiesen 외 2인. Facial Asymmetry: Current review. Dental Press J Ortho(2015) $111 \mathrm{p}$

20. Cheng \& Lo. Facial Asymmetry: Etiology, Evaluation and Management. Chang Gung $\operatorname{Med}(2011)$
21. 최진영, 백승학. 턱교정 수술 및 안면윤곽술. 범 문에듀케이션(2015) 229-230

22. 박지영. 안면비대칭과 척추측만증의 관계 연구. 서울대학교치의학대학원 (2015) p.3

23. 손병화 외 3 인. 두개안면 성장 발육의 이론과 임상. 대한나래출판사 (2007) p.81 82

24. M.INUI 외 1 인. Facial asymmetry in temporomandibular joint disorders. Journal of Rehabilitation(1999)

25. 최진영, 백승학. 턱교정 수술 및 안면윤곽술. 범 문에듀케이션(2015) 229-230

26. 김왕식 외 2 인. 안면비대칭자의 3 차원 전단 단 층 사진 분석에서 경,연조직간의 비대칭 정도 차이. 대한치과교정학회지 (2005)

27. 장영일. FACIAL ASYMMETRY. 대한치과교 정학회지 (1991) p.255

28. 권찬영 외 2 인. 안면비대칭에 대한 한의학적 치 료 효과: 증례 보고. 대한침구학회지 (2017)

29. 서연주 외 9 인. 기능적 뇌척주 요법을 병행한 한방치료가 턱관절장애가 있는 교통사고 환자에 미치는 영향. 대한침구의학회지(2016) p.15

30. 인창식 외 2 인. 경추부 근육 긴장 이상에 대한 턱관절 경락음양균형 치료시 영상의학적으로 관 찰된 경추 정렬 개선 효과. 동의생리병리학회지 (2008) p.462

31. 윤일선 외 1 인. 군집분석법에 의한 안면비대칭 분류. 대한치과의사협회지 (2001)

32. M.INUI외 1인. Facial asymmetry in temporomandibular joint disorders. Journal of Rehabilitation(1999)

33. 서연주 외 9인. 기능적 뇌척주요법을 병행한 한 방치료가 턱관절장애가 있는 교통사고 환자에 미치는 영향. 대한침구의학회지(2016) p.153

34. 인창식 외 4인. 침구경락 음양론의 새로운 발전, 기능적 뇌척주 요법 (FCST). 대한경락경혈학회 지(2005) 
35. 박지영. 안면비대칭과 척추측만증의 관계 연구. 서울대학교치의학대학원 (2015)

36. 김현, 황현식. 안면비대칭환자의 natural head position에 대한 정모 두부 방사선 사진 연구. 대한치과교정학회지 (2000)

37. 이혜수. 상악궁의 비대칭과 악골의 비대칭, 경추 및 흉추 측만의 상관관계. 서울대학교 치의학대 학원(2016)

38. 박지영. 안면비대칭과 척추측만증의 관계 연구. 서울대학교치의학대학원 (2015)

39. 인창식 외 2 인. 경추부 근육 긴장 이상에 대한
턱관절 경락음양균형 치료시 영상의학적으로 관 찰된 경추 정렬 개선 효과. 동의생리병리학회지 (2008)

\section{ORCID}

신정민 https://orcid.org/0000-0002-0356-4747

안진향 https://orcid.org/0000-0003-0995-9456

이진혁 https://orcid.org/0000-0002-2263-603X 